\title{
Yabancı Dil Olarak Türkçe Öğrenenlerin Bağdaşıklık Araçlarını Kullanma Düzeyinin Değerlendirilmesi*
}

\author{
Dr. Aliye Nur Ercan Güven \\ Eskişehir Osmangazi Üniversitesi, \\ Ĕ̆itim Fakültesi \\ Türkçe ve Sosyal Bilimler Eğitimi Bölümü \\ anercan@ogu.edu.tr
}

\author{
Doç. Dr. Şerife Akpınar \\ Necmettin Erbakan Üniversitesi, \\ Ahmet Keleşoğlu Eğitim Fakültesi \\ Türkçe ve Sosyal Bilimler Ĕ̆itimi Bölümü \\ sakpinar@erbakan.edu.tr
}

Öz

Bağdaşıklık, metnin yüzey yapısıyla ilgili olup dil bilgisel unsurlarla kendini gösteren bir metinsellik ölçütüdür. Çalışmanın genel amacı; yabancı dil olarak Türkçe öğrenenlerin, yazılı anlatımlarında bağdaşıklık araçlarını kullanma düzeylerinin değerlendirilmesidir. Çalışmada ayrıca, öğrencilere yazdırılan iki ayrı metnin bu düzeyler açısından karşılaştırılması ve belirlenen değişkenler açısından incelenmesi de hedeflenmiştir. Çalışma, türü açısından betimsel nitelikte olup tarama yönteminde gerçekleştirilmiştir. Metinler üzerinde doküman incelemesi yapılmıştır. Çalışmaya, altı farklı üniversitenin Türkçe öğretim merkezinden; B2 düzeyinde 163, C1 düzeyinde ise 117 olmak üzere toplam 280 öğrenci katılmıştır. Veriler, öğrencilere sunulan üç farklı form aracıllğı̆yla toplanmıştır: birey tanıma formu, yönlendirilmiş yazma formu ve serbest yazma formu. Toplanan verilerin analizi için, nitel verilerin sayısallaştırılmasına başvurulmuştur. Çalışma sonucunda; iki metnin toplamında öğrenci başına düşen bağdaşıklık ögesi kullanımı 50,32 olarak tespit edilmiştir. Serbest konuda yazılan metinlerde bağdaşıklık araçları kullanımının, yönlendirilmiş olarak yazılmış metinlere göre daha fazla olduğu saptanmıştır. Sonuçlar, bağdaşıklık araçlarını kullanma düzeyinin bazı değişkenler açısından farklılaştığını göstermektedir.

Anahtar Kelimeler: Yabancı dil olarak Türkçe, yazılı anlatım, bağdaşıklık araçları.

\section{Evaluation of Cohesive Device Uses of Learners of Turkish as a Foreign Language}

\begin{abstract}
Cohesion is related with the surface level of text and can be inferred through grammatical features. The main aim of this study is to determine the level of cohesion of texts written by international students learning Turkish as a foreign language. Furthermore, this study aims to compare and contrast the two different texts written by the learners based on level of cohesion, and investigate the differences with determined variables. This study

* Bu makale, Doç. Dr. Şerife Akpınar danışmanlığında tamamlanan Üniversitelerin Dil Öğretim Merkezlerinde Türkçe Öğrenen Yabancıların Yazılı Anlatımlarının Bă̆daşıklık ve Tutarlılık Düzeylerinin İncelenmesi başlıklı Doktora tezinden üretilmiştir.


can be identified as a descriptive research that follows survey method. Document analysis was carried out on the learner texts. The participants of the study are 280 international students from six different universities. There were 163 students with B2 and 117 students with $\mathrm{C} 1$ language proficiency levels. The data were gathered through three different forms given to the participants: general background information form, guided-writing form, and free-writing form. In order to carry out the data analysis procedure, qualitative data were digitalized. The results of the study; including both of the texts, the use of cohesion element per student was determined as 50,32. The results show that the level of cohesion in freewriting was higher than the level of cohesion in guided-writing. The results show that the level of using cohesive devices varies in terms of some variables.

Keywords: Turkish as a foreign language, written discourse, cohesive devices. 


\section{GİRIŞ}

Metnin yüzey yapısında, dil bilgisel unsurlarla kendini gösteren bağdaşıklık, Dillon'a (1992, s. 9) göre; cümleleri birbirine bağlayarak tek bir metin olarak okunabilmesini sağlayan niteliktir. Bamberg (1983, s. 418) bağdaşıklığı, küçük söylem parçalarını bir araya getirmenin yanı sıra metin boyunca süren ve daha büyük söylem parçalarını birbirine bağlayan bir dil bilim sistemi şeklinde tanımlar.

Bağdaşıklık, bir metinde düşünceleri birbirine bağlayan dilsel araçların kullanılması yoluyla sağlanır (Struthers, Lapadat \& MacMillan, 2013, s. 187). Palmer (1999, s. 67), bağdaşıklığın metinlerin anlamlandırılmasına katkı sağladığı düşüncesindedir. Halliday ve Hassan (1987, s. 4) da aynı görüşte olup bağdaşıklığın metin içinde var olan anlam ilişkilerine atıfta bulunduğunu ve onu bir metin olarak tanımladığını söylerler.

Bağdaşıklık ögeleri; metni oluşturan farklı bölümlerin, dilsel bir bütünlük sağlayacak biçimde bir araya gelmelerine katkı sağlar (Toptaş, 2016, s. 1088). Ancak Seçkin, Arslan ve Ergenç'in (2014, s. 352) de ifade ettiği şekilde; bir metinde bağdaşıklık ögelerinin çok kullanılması, o metnin yazarının dil ve anlatımda çok başarılı olduğu anlamı taşımayacağı gibi, az kullanılması da yazarın anlatım açısından yetersiz olduğunun bir göstergesi değildir. Esas olan; bağdaşıklık unsurlarından yeterince yararlanarak metni zenginleştirmektir. Bahsi geçen ögelerin yetersiz kullanılması durumunda ise, metnin alıcısı/okuru tarafından anlaşılmasını güçleşecektir. Melanlığlu da (2017, s. 118) bağdaşıklık unsurlarının tam olarak kullanılamamasının metinde sunulan ana düşüncenin mantıklı ve planlı bir şekilde okura ulaşmasını engellediği görüşündedir.

Alanyazın tarandığında, bağdaşıklığın farklı sınıflandırmaları görülür. Kimi araştırmacılar (Altunkaya, 1987; Halliday \& Hassan, 1987), bağdaşıklığın tüm alt boyutlarını ayrı ayrı düşünerek gönderim, değiştirim, eksilti, bağlaçlar ve sözcüksel bağdaşıklık olarak beş boyut belirlemişlerdir. Bazı araştırmacılar (Dilidüzgün, 2017; Torusdağ \& Aydın, 2017) ise, bağdaşıklık unsurlarını dil bilgisel ve sözcüksel olarak iki ana başlıkta ele almışlardır.

$\mathrm{Bu}$ çalışma için, bağdaşıklık araçlarını sınıflandırmada -araştırmacılarca (Çelik \& Demirbilek, 2006; Erkul, 2007; Subaşı-Uzun, 1995; Tekşan, 2013; Toptaş, 2016) da benimsenen görüş doğrultusunda- iki başlık oluşturulmuştur: Gönderimsel ve biçimsel-sözlüksel.

\section{Gönderimsel Bağdaşıklık}

Gönderimsel bağdaşıklık, metin içinde belirtilen ya da belirtilecek olan bir unsurun aynı şekilde yinelenmesi yerine farklı bir dil bilgisi unsuru kullanılarak anımsatılmasıdır. Kullanılan yeni ifade ile önceki sözcüğe hatta paragrafa bile gönderim yapılabilir. Bir metinde verilen bilgilerin, iletilmek istenen duyguların ya da mesajların alıcıya (okuyucu veya dinleyici) doğru aktarılabilmesi ve metinde anlam karışıklığına yol açmamak için yapılan gönderimlerin karşılığının net olması gerekmektedir.

Gönderim bazı dil bilgisel unsurlar kullanılarak yapılır. Araştırmacıların (Coşkun, 2005, s. 54; Torusdağ \& Aydın, 2017, s. 99; Uzun-Subaşı 2004, s. 30) da belirttiği gibi, gönderimde kullanılan ögeler tek başlarına sözlüksel bir anlam taşımazlar; anlamsal değerlerini, metinde başka bir ögeyle kurdukları gönderim ilişkisi sayesinde kazanırlar.

\section{1. Öncül/bağımsız gönderim}

Öncül/bağımsız gönderim ögeleri; kişi adılları, dönüşlülük adılı, gösterme adılları, aitlik adılı, belirsizlik adılları, gösterme sıfatları ve belirteçlerdir. 


\subsection{Ardıl/bağımlı gönderim}

Bir sözcüğe bağlanarak anlam kazanan birimler olan eklerin kurdukları gönderim ilişkisidir. Araştırmacılar, adlara eklenen; iyelik ekleri (Aydın, 2012, s. 387; Dilidüzgün, 2017, s. 52; İşeri, 2017, s. 117; Subaş1-Uzun, 1995, s. 38; Yaylagül, 2015, s. 391), belirtme durumu eki (Dilidüzgün, 2017, s. 52; İşeri, 2017, s. 117; Subaş1-Uzun, 1995, s. 38), ilgi eki (Subaş1-Uzun, 1995, s. 38) ile çekimli eylemlerde bulunan kişi eklerinin (Aydın, 2012, s. 387; Dilidüzgün, 2017, s. 52; İşeri, 2017, s. 117; Subaş1-Uzun, 1995, s. 38; Torusdağ \& Aydın, 2017, s. 129; Yaylagül, 2015, s. 391) metinlerde gönderim ilişkisi kurarken kullanılabildiğinden bahseder.

\section{Biçimsel-Sözlüksel Bağdaşıklık}

Biçimsel-sözlüksel bağdaşıklık genel olarak sözcüklerle sağlanan bağdaşıklık türüdür. Bu çatı altında; değiştirim, eksilti, bağlaçlar ve sözcük ilişsileri bulunmaktadır.

\subsection{Değiştirim}

Değiştirim "bir yapıda bir birimin yerine başka bir birim koyma işlemi" (İmer, Kocaman \& Özsoy, 2011, s. 82) olarak tanımlanabilir. Türkçe metinlerde değiştirim için sıklıkla kullanılan bazı sözcükler vardır. Bu sözcükler, tek başlarına bir anlam taşımayan ancak yerlerini aldıkları unsurlara göre anlam kazanan birimlerdir. Böylelikle metinde bağlama dayalı bir bağdaşıklık oluştururlar. Değiştirim için sıkça kullanılan yapılar; öyle, böyle, şöyle (Güven, 2014, s. 601; İşeri, 2017, s. 119; Yaylagül, 2015, s. 393) ve aynı (Güven, 2014, s. 601) sözcükleri ile yapmak (Dilidüzgün, 2017, s. 55) eylemidir.

Değiştirim, kullanılan yeni birimin hangi sözcük, sözcük grubu ya da tümcenin yerini aldığına göre; ada, eyleme ve tümceyeltümceciğe dayalı olarak üç farklı biçimde yapilabilmektedir.

\subsection{Eksilti}

Eksilti, en yalın ifadeyle "eksik fakat anlaşılır tümce kullanma biçimidir" (Torusdağ \& Aydın, 2017, s. 137). Halliday ve Hassan (1987, s. 142) eksilti için, -metinde söylenmemesine rağmen- anlaşılan şey, açıklamasını yapar. Metinlerde eksiltiyi tercih etme nedenleri; iletişimde zamandan tasaaruf, en az çaba ilkesi ve tekrara düşmekten kaçınma olarak düşünülebilir (Beaugrande \& Dressler, 1986, s. 69; Üstünova, 2002, s. 111).

Metinlerde eksiltili ifadeler kullanmak, anlatıcıya kolaylık sağlar. Bazı kaynaklar eksiltiyi, değiştirimin alt bir sınıfı olarak değerlendirmektedir. Hatta eksiltinin sıfır değiştirim diye adlandırılabileceğini belirten çalışmalar (Elyıldırım, 2008, s. 131; Halliday \& Hassan, 1987, s. 142) mevcuttur. Ancak aralarındaki en önemli ayrım; eksiltide metinden çıarılan sözcüğün yerini yenisinin almaması, o ögenin yerinin boş kalmasıdır (İşeri, 2017, s. 120; Karabağ \& İşsever, 1996, s. 224).

Eksilti, metinlerde ortak ögenin (özne, nesne ya da tümleç), tamlayanın, tamlananın, tümcenin/tümceciğin veya eklerin düşürülmesi şeklinde yapılabilir.

\subsection{Bağlaçlar}

Bağlaçlar sözcükleri, sözcük gruplarını, tümce ya da paragrafları biçimsel ve anlamsal açıdan bağlayan, aralarında irtibat kurmaya yarayan dil bilgisi unsurlarıdır.

Araştırma kapsamında yapılan incelemeler, bağlaçların işlevlerine göre sınıflandığ1 çalışmalardan (Demir, 2004; Ergin, 2009; Korkmaz, 2007) yararlanılarak oluşturulan yedi gruba göre yapılmıştır. Oluşturulan bu gruplar; açıklama, çelişki-karşıtlık, denkleştirme- 
karşılaştırma-tercih, neden-sonuç, örnekleme, pekiştirme-üsteleme ve sıralama bağlaçları şeklindedir.

\subsection{Sözcük ilişkileri}

Metin oluşturulurken bir araya getirilen sözcüklerin birbiriyle ilişkili, anlamsal bir bağlantı içinde bulunması gerekmektedir. Metinde yer alan cümleler arasındaki bağlar; sözcüklerin aynı şekilde yinelenmesi şeklinde olabileceği gibi yapının yinelenmesi şeklinde de görülebilir. Yapılan bu yinelemeler, metnin akıcılığını artırır ve kolay anlaşılmasını sağlar. Araştırmacılar (Aşkın-Balcı, 2018, s. 84; Ayata-Şenöz, 2005, s. 63) da yinelemelerin metnin bağdaşıklığına katkı sağladığı konusunda görüş belirtmektedirler.

Yineleme dışında metinlerdeki sözcük ilişkilerini sağlamanın başka yolları da bulunmaktadır. Aynı kökten veya bağlama uygun sözcük kullanımı ile de metnin bağlantısı sürdürülebilir.

\section{AMAÇ VE ÖNEM}

Bağdaşık metinler; yazarın anlatmak istediği konuyu, iletmek istediği mesajı daha doğru ve anlaşılır şekilde aktarmasına olanak tanır. Böylelikle daha sağlıklı bir iletişim sağlanır. Bu çalışmanın genel amacı; üniversitelerin dil öğretim merkezlerinde Türkçe öğrenen yabancı öğrencilerin, yazılı anlatımlarında bağdaşıklık araçlarını kullanma düzeylerinin incelenmesidir. Çalışma kapsaminda öğrencilere, yönlendirilmiş ve serbest olmak üzere, iki ayrı metin yazdırılarak metinlerin bağdaşıklık düzeylerinin karşılaştırılması amaçlanmıştır. Çalışmada ayrıca, metinlerin bağdaşıklık düzeylerinin belirlenen değişkenler açısından farklılaşıp farklılaşmadığı değerlendirilmek istenmiştir.

Türkiye'de üniversite eğitimi alacak bireyler, başlangıçta istenilen dil yeterliğini sağlayamadıkları takdirde üniversitelerin bünyelerinde Türkçe hazırlık eğitimi almaktadırlar. Bu eğitim süresince, öğrencilerin Türkçe anlama ve anlatma becerilerine yönelik gelişimleri sağlanmaya çalışılır. Dil eğitimi sonunda, öğrencilerin dil becerileri açısından lisans eğitimine hazır ve uygun hâle geldiğini belirlemede kullanılan göstergelerden biri de yazdıkları metinlerdir. Bu metinlerin ne düzeyde bağdaşık oldukları, yazarlarının dili ne derece iyi kullanabildikleri ile ilişkilendirilebilir.

Alanyazın tarandığında, Karakoç-Öztürk ve Dağıstanlıŏglu (2018) ile Yıldırım'ın (2016), yabancı dil olarak Türkçe öğrenen B1 düzeyindeki öğrencilere öyküleyici metinler; Aramak'ın (2016) ise, C1 düzeyindeki öğrencilere bilgilendirici metinler yazdırarak çalışmalar yaptıkları görülür. Ayrıca Mantı (2017), düzeyleri A2, B1, B2 ve C1 olan Mısırlı öğrencilerle bir çalışma gerçekleştirmiştir. Ancak değinilen tüm bu çalışmalarda; tek bir dil öğretim merkezinde, daha sınırlı sayıda öğrenciye, sadece bir metin yazdırılarak incelemeler yapıldığ 1 fark edilmektedir. Yine bahsi geçen çalışmalardan bir kısmının (Aramak, 2016; Mantı, 2017; Yıldırım, 2016) metinleri, Coşkun (2005) ve/veya Karatay'ın (2010) ölçekleri aracılığıyla irdeledikleri söylenebilir.

$\mathrm{Bu}$ çalışmanın örneklem sayısı, verilerin toplandığı ulusların ve öğrencilerin dil düzeylerinin çeşitliliğgi açılarından farklılık gösterdiği söylenebilir. Ayrıca veriler, her bir öğrencinin iki ayrı metninden elde edilmiştir. Yönlendirilmiş ve serbest olarak, iki ayrı türde, yazdırılan metinlerdeki bağdaşıklık ögelerinin kullanılma düzeyinin birbiriyle kıyaslanması, bu çalışmayı farklı kılan bir başka özelliktir. Yine metinlerin incelenmesinde 
kullanılan ölçekler de daha önceki çalışmalardan yola çıkılarak uzman görüşleri doğrultusunda tarafımızdan geliştirilmiştir.

\section{YÖNTEM}

\section{Araştırma Modeli}

$\mathrm{Bu}$ araştırma, türü bakımından betimsel nitelikte olup tarama yönteminde gerçekleştirilmiştir. Betimsel çalışmalarda, evren içinden belirlenen örneklem gruptan toplanan veriler, olduğu gibi betimlenir ve sayısallaştırılarak sunulur.

Çalışmada öğrencilerin yazdıkları metinler üzerinde doküman incelemesi yapılmıştır. $\mathrm{Bu}$ inceleme, "araştırılması hedeflenen olgu veya olaylar hakkında bilgi içeren yazılı materyallerin analizini kapsar" (Yıldırım \& Şimşek, 2011, s. 187).

\section{Çalışma Grubu}

$\mathrm{Bu}$ çalışma, üniversitelerin dil öğretim merkezlerinde Türkçe öğrenen B2 ve C1 düzeyinde dil becerisine sahip öğrenciler ile gerçekleştirilmiştir. Çalışmanın bu dil seviyesindeki öğrencilerle yapılmasının nedenleri; açık ve anlaşılır yazılar yazabilecek, düşüncelerini bir bağlam içerisinde konudan sapmadan aktarabilecek, yazdıkları arasında bağlantılar kurabilecek, belli dil bilgisi yapılarını kavramış, nihayetinde Türkçe yazı yazmada ilerleme kaydetmiş durumda olmalarıdır.

Çalışma grubu, olasılığa bağlı olmayan örneklem tekniklerinden amaçlı örneklemeye göre oluşturulmuştur. Bu teknikte "araştırmacının amacına en uygun birimler örnekleme dâhil edilmektedir" (Gürbüz \& Şahin, 2018, s. 132). Bu kapsamda çalışma, İç Anadolu bölgesinde farklı illerde yer alan üniversitelerin dil öğretim merkezlerinde Türkçe eğitim alan ve uygulamanın gerçekleştiği tarihlerde $\mathrm{B} 2$ veya $\mathrm{C} 1$ düzeyinde olan gönüllü öğrencilerle yürütülmüştür. Çalışma grubu birden fazla kurumdan seçilerek öğretici, mekân, ders kitabı vb. farklılıkların etkisinin azaltılması ve grubun çeşitlendirilmesi hedeflenmiştir.

Uygulamaya katılan yabancı öğrencilerin dil öğretim merkezlerine ve dil düzeylerine ilişkin dağılımı Tablo 1'de verilmiştir:

Tablo 1: Öğrencilerin Dil Düzeylerine Göre Dağılımı

\begin{tabular}{lccc}
\hline \multicolumn{1}{c}{ Merkezler* } & Düzey & & Toplam \\
\hline Selçuk Ü - TÖMER & B2 & C1 & \\
\hline Necmettin Erbakan Ü - KONDİL & 70 & 45 & 115 \\
\hline Ankara Yıldırım Beyazıt Ü - DİLMER & 63 & 5 & 68 \\
\hline Gazi Ü - TÖMER & 0 & 30 & 30 \\
\hline Eskişehir Osmangazi Ü - TÖMER & 10 & 19 & 29 \\
\hline Nevşehir Hacı Bektaş Veli Ü - TÖMER & 20 & 5 & 25 \\
\hline Toplam & 0 & 13 & 13 \\
\hline
\end{tabular}

*Merkezler çalışmaya katılan toplam öğrenci sayısı göz önüne alınarak sıralanmıştır.

Çalışmaya altı farklı üniversitenin Türkçe öğretim merkezinden, B2 düzeyinde 163 ve C1 düzeyinde ise 117 öğrenci olmak üzere toplam 280 öğrenci katılmıştır. Öğrencilerin yaş ve cinsiyetlerine göre dağılımları Tablo 2' de yer almaktadır: 
Tablo 2: Öğrencilerin Cinsiyet ve Yaşlarına Göre Dağılımı

\begin{tabular}{lcccc}
\hline & \multicolumn{2}{c}{ Yaş } & Toplam \\
\hline Cinsiyet & $\mathbf{1 8 - 2 5}$ yaş & $\mathbf{2 6 - 3 3}$ yaş & \\
\hline Kadın & 88 & 17 & 105 \\
\hline Erkek & 131 & 44 & 175 \\
\hline Toplam & 219 & 61 & 280 \\
\hline
\end{tabular}

Çalışmada 105 kadın ve 175 erkek öğrenci bulunmaktadır. Öğrencilerin 219'u 18-25 yaş aralığında iken 61 tanesi 26-33 yaş aralığında yer almaktadır.

\section{Veri Toplama Araçları}

Çalışma kapsamındaki veriler, öğrencilere sunulan üç farklı form yoluyla toplanmıştır. Kullanılan bu araçlar; birey tanıma formu, yönlendirilmiş yazma formu ve serbest yazma formudur.

Birey tanıma formu; öğrencilerin demografik bilgileri ile çalışmanın verilerini etkileyebileceği düşünülen değişkenlere yönelik hazırlanmıştır.

Yönlendirilmiş yazma formu; öğrencilerin kendilerine verilen yönerge ve resimler doğrultusunda bir metin oluşturmalarının beklendiği formdur. Birbirinin devamı niteliğinde sekiz kare resimden oluşan bu formda, bir olay tasvir edilmektedir. Yönlendirilmiş yazma formu 14 Mart 2017 tarihinde www.ogretimhane.com internet adresinden elde edilen resimlere araştırmacı tarafından uygulama yönergesi eklenmesi yoluyla oluşturulmuştur. Resimden yazma etkinliğinde öğrencilerden beklenen; belirlenen sırayı takip etmeleri böylelikle yazıdaki devamlılığı ve bütünlüğü sağlamalarıdır.

Serbest yazma formu; öğrencilere verilen beş farklı yazma konusundan seçecekleri bir konu hakkında bir metin yazmalarına yönelik hazırlanmıştır. Serbest yazılacak metinler için on farklı konu belirlenmiştir. Alan uzmanları, belirlenen konuları -çalışmanın kapsamını da göz önünde bulundurarak- uygulama yapılacak dil düzeylerine uygunluğu açısından değerlendirmiştir. Uzman görüşleri doğrultusunda en fazla puan alan beş konu öğrencilere sunulmuştur.

Öğrenci metinlerinin bağdaşıklık düzeylerini incelemek için ise, alanyazın taranarak araştırmacı tarafından oluşturulan Bağdaşıklık Düzeyi Değerlendirme Çizelgesi kullanılmıştır. $\mathrm{Bu}$ çizelgenin oluşturulmasında yararlanılan kaynaklar şöyle sıralanabilir: (Bae, 2001; Coşkun, 2005; Coşkun-Ögeyik, 2008; Dilidüzgün, 2017; Erkul, 2007; Günay, 2013; Halliday \& Hassan, 1987; Karabă̆ \& İşsever, 1996; Özkan, 2004; Struthers vd., 2013; Tierney \& Mosenthal, 1981; Toptaş, 2016; Uzun, 2013; Yaylagül, 2015). Oluşturulan değerlendirme çizelgesinin kapsam geçerliğine bakılmıştır. Araştırmacılar (Baykul, 2010, s. 226; Büyüköztürk, Kılıç-Çakmak, Akgün, Karadeniz \& Demirel, 2015, s. 117; Karasar, 2011, s. 151; Özbek, 2011, s. 70-71) bu geçerliği belirlemede kullanılacak yollardan birinin uzman görüşüne başvurmak olduğunu belirtirler. Bu sebeple, çizelge alan uzmanlarının görüşü doğrultusunda değerlendirilmiş ve alınan dönütlerle gerekli düzenlemeler yapılmıştır.

\section{Verilerin Toplanması}

Çalışma verilerini toplamaya başlamadan önce, ön uygulama yapılmıştır. $\mathrm{Bu}$ uygulamadan alınan dönütler doğrultusunda öğrencilere yönlendirilmiş yazma için kırk, serbest yazma konusu için ise elli dakika verilmesi uygun görülmüştür. Ancak daha uzun süre yazmak isteyenlere de esneklik tanınmıştır. 
Veriler, kurumların akademik takvimlerine uygun olacak şekilde, 18 Nisan 2017 - 8 Haziran 2017 tarihleri arasında toplanmıştır. Veri toplama araçları dağıtıldıktan sonra, katılımcılar araştırmanın konusu, amacı ve formları nasıl dolduracakları konusunda bilgilendirilmiştir. Ayrıca çalışmaya katılma konusunda gönüllülük aranmış ve istenildiği takdirde çalışmadan ayrılabilecekleri hatırlatılmıştır.

\section{Verilerin Analizi}

Çalışmada, nitel verilerin sayısal analizinden yararlanılmıştır. Yıldırım ve Şimşek (2011, s. 242-243), nitel verilerin sayısallaştırılmasının; güvenirliği artırdığını, yanlılığı azalttığını ve ortaya çıkan kategoriler arasında karşılaştırma yapma imkânı sağladığını belirtir.

Öğrencilerin yazdıkları metinlerin bağdaşıklık düzeyleri incelenirken büyük harf kullanımı, harf eksiği, harflerin siralamasında hatalar, ses uyumuna uygun olmayan kullanımlar gibi yazım yanlışları dikkate alınmamıştır.

Cohen ve Manion (1998, s. 89-90), verileri üzerinde istatistiksel analiz yapmayı planlayan birçok araştırmacının, örneklem büyüklüğü olarak en az otuz sayısında hemfikir olduklarını belirtir. Bu görüş doğrultusunda, metinlerin bağdaşıklık düzeylerinin değişkenlere göre incelendiği yerlerde; temsil edilen grup sayısı otuzdan az sayıda ise o grup analiz dışı bırakılmıştır.

Metinlerin bağdaşıklık düzeyine ilişkin bulguların güvenirliği için değerlendirici içi güvenirliğe başvurulmuştur. Verilerin dikkat dağılması, yorgunluk vb. kaynaklı hatalardan etkilenmemesi için araştırmacı tüm verileri inceleyip puanlamayı tamamladıktan üç ay sonra tekrar bir inceleme yapmış ve frekansların birbiriyle uyumuna bakılmıştır. Tereddütte kalınan durumlarda ise, Türkçe eğitiminden iki uzmana danışılıp ortak bir karar alınmıştır.

Bağlaçların türlere göre ayrımında, kullanıldığı bağlam göz önünde bulundurulmuştur. Aynı sözcüğün yinelenmesine, kullanılan sözcüğün her bir kullanımı dâhil edilmiştir. Aynı kavram alanından sözcük kullanımında ise, birden fazla sözcügüun işaret ettiği kavram tek olarak sayılmıştır.

Metinlerdeki bağdaşıklık ögesi kullanımına ilişkin veriler Microsoft Excel programından yararlanılmıştır. Neuman (2016, s. 500), bir değişkenin sayısal verilerini tanımlamanın en kolay yolunun bir sıklık dağılımı kullanmak olduğunu belirtir. $\mathrm{Bu}$ görüşten hareketle, çalışmanın verileri oluşturulan tablolarda, frekans ve yüzde bilgileri verilerek açıklanmıştır. Ayrıca bireysel farklılıkların metinlerin bağdaşıklık düzeylerine etkisi ortalamalarla ele alınmıştır.

\section{BULGULAR VE YORUM}

Yabancı dil olarak Türkçe öğrenenlerin yönlendirilmiş ve serbest şekilde iki farklı türde yazdıkları metinlerin bağdaşıklık düzeylerine ilişkin bulgular şu şekildedir: 
Tablo 3: Yazma Biçimine Göre Bağdaşıklık Düzeyleri

\begin{tabular}{lcccccc}
\hline \multirow{2}{*}{ N: 280} & \multicolumn{2}{c}{ Yönlendirilmiş } & \multicolumn{2}{c}{ Serbest } & \multicolumn{2}{c}{ Toplam bağdaş1klık } \\
\cline { 2 - 7 } & $\mathrm{F}$ & $\chi$ & $\mathrm{F}$ & $\chi$ & $\mathrm{F}$ & $\chi$ \\
\hline Gönderimsel & 2485 & 8,87 & 2792 & 9,97 & 5277 & 18,85 \\
\hline $\begin{array}{l}\text { Biçimsel- } \\
\text { sözlüksel }\end{array}$ & 3999 & 14,28 & 4815 & 17,20 & 8814 & 31,48 \\
\hline Toplam & 6484 & 23,16 & 7607 & 27,17 & 14091 & 50,32 \\
\hline
\end{tabular}

Çalışmaya katılan öğrencilerin yazdıkları iki farklı metin incelenmiş ve toplamda 14091 bağdaşıklık ögesi saptanmıştır. Bu durumda, iki metin için, öğrenci başına düşen toplam bağdaşıklık ögesi kullanımının $(\chi=50,32)$ olduğu görülür. Serbest konuda yazılan metinlerdeki bağdaşıklık düzeyi ortalaması $(\chi=27,17)$ iken yönlendirilmiş yazılarda $(\chi=23,16)$ düzeyindedir. Bu bulguya dayanarak öğrencilerin serbest yazmada daha bağdaşık metinler yazdıkları söylenebilir.

Metinlerdeki bağdaşıklık ögeleri türlerine göre ayrıldığında, öğrencilerin yazılarında gönderimsel bağdaşıklık ögelerini $(\chi=18,85)$, biçimsel-sözlüksel bağdaşıklık ögelerini ise $(\chi=31,48)$ ortalamayla kullandıkları görülür. Bu bulgu, öğrencilerin daha çok biçimselsözlüksel bağdaşıklığı kullandıklarını gösterir. Ayrıca serbest yazma metinlerinde kullanılan hem gönderimsel hem de biçimsel-sözlüksel bağdaşıklık ögesi, yönlendirilmiş yazma metinlerinde kullanılandan fazladır.

Tablo 4: Yazma Biçimine Göre Gönderimsel Bağdaşıklık Kullanımı

\begin{tabular}{lcccccc}
\hline & \multicolumn{2}{c}{ Yönlendirilmiş } & & Serbest & \multicolumn{2}{c}{ Toplam bağdaşıklık } \\
\hline & $\mathrm{F}$ & $\chi$ & $\mathrm{F}$ & $\chi$ & $\mathrm{F}$ & $\chi$ \\
\hline $\begin{array}{l}\text { Öncül/Bă̆ımsız } \\
\text { G. }\end{array}$ & 2056 & 7,34 & 2106 & 7,52 & 4162 & 14,86 \\
\hline Kişi adılları & 675 & 2,41 & 945 & 3,37 & 1620 & 5,79 \\
\hline Dönüşlülük adılı & 35 & 0,12 & 62 & 0,22 & 97 & 0,35 \\
\hline Gösterme adılları & 76 & 0,27 & 305 & 1,09 & 381 & 1,36 \\
\hline Aitlik adılı & 0 & 0 & 3 & 0,01 & 3 & 0,01 \\
\hline $\begin{array}{l}\text { Belirsizlik } \\
\text { adılları }\end{array}$ & 185 & 0,66 & 274 & 0,98 & 459 & 1,64 \\
\hline $\begin{array}{l}\text { Gösterme } \\
\text { slfatları }\end{array}$ & 460 & 1,64 & 230 & 0,82 & 690 & 2,46 \\
\hline Belirteçler & 625 & 2,23 & 287 & 1,02 & 912 & 3,26 \\
\hline Ardıl/Bağımlı G. & 429 & 1,53 & 686 & 2,45 & 1115 & 3,98 \\
\hline Kişi ekleri & 49 & 0,17 & 329 & 1,17 & 378 & 1,35 \\
\hline $\begin{array}{l}\text { İyelik ekleri } \\
\text { İlgi eki }\end{array}$ & 135 & 0,48 & 205 & 0,73 & 340 & 1,21 \\
\hline $\begin{array}{l}\text { Belirtme durumu } \\
\text { eki }\end{array}$ & 159 & 0,57 & 111 & 0,40 & 270 & 0,96 \\
\hline
\end{tabular}

Öğrenci yazılarındaki gönderimsel bağdaşıklık unsurları değerlendirildiğinde, kullanılan öncül/bağımsız gönderim ortalamasının $(\chi=14,86)$ iken ardıl/bağımlı gönderim ortalamasının $(\chi=3,98)$ olduğu anlaşılmaktadır. Bağımsız gönderim ortalamalarında yazma 
biçimlerine göre çok değişiklik olmamakla birlikte bağımlı gönderimin serbest yazma metinlerinde daha çok tercih edildiği söylenebilir.

Yine Tablo 4'te, bağımsız gönderim olarak kişi adıllarının diğer unsurlardan daha fazla kullanıldığı görülmektedir. Aitlik adılı ise, metinlerde en az kullanılmış gönderim ögesidir. Bağımlı gönderim unsurlarının kullanımında ise ilk sırada kişi ekleri görülürken iyelik eklerinin de ona yakın bir oranda kullanıldığı söylenebilir.

Tablo 5: Yazma Biçimine Göre Değiştirim Kullanımı

\begin{tabular}{lcccccc}
\hline & Yönlendirilmiş & Serbest & \multicolumn{3}{c}{ Toplam bağdaşıklık } \\
\hline & $\mathrm{F}$ & $\chi$ & $\mathrm{F}$ & $\chi$ & $\mathrm{F}$ & $\chi$ \\
\hline Değiştirim & 69 & 0,25 & 116 & 0,41 & 185 & 0,66 \\
\hline $\begin{array}{l}\text { Ada } \\
\text { dayalı }\end{array}$ & 1 & 0,003 & 20 & 0,07 & 21 & 0,07 \\
\hline $\begin{array}{l}\text { Eyleme } \\
\text { dayalı }\end{array}$ & 3 & 0,01 & 1 & 0,003 & 4 & 0,01 \\
\hline $\begin{array}{l}\text { Tümceye/ } \\
\text { Tümceciğe } \\
\text { dayalı }\end{array}$ & 65 & 0,23 & 95 & 0,34 & 160 & 0,57 \\
\hline
\end{tabular}

Tablo 5 incelendiğinde, metinlerde değiştirim kullanım ortalamasının $(\chi=0,66)$ olduğu görülür. Bu oranın büyük bir kısmını, tümceye/tümceciğe dayalı yapılan değiştirimler oluşturmaktadır. Serbest yazma metinlerinde değiştirim kullanım oranı yönlendirilmiş olarak yazılan metinlere göre daha yüksektir.

Tablo 6: Yazma Biçimine Göre Eksilti Kullanımı

\begin{tabular}{lcccccc}
\hline & \multicolumn{2}{c}{ Yönlendirilmiş } & \multicolumn{2}{c}{ Serbest } & \multicolumn{2}{c}{ Toplam bağdaşıklık } \\
\hline & $\mathrm{F}$ & $\chi$ & $\mathrm{F}$ & $\chi$ & $\mathrm{F}$ & $\chi$ \\
\hline Eksilti & 293 & 1,05 & 438 & 1,56 & 731 & 2,61 \\
\hline $\begin{array}{l}\text { Ortak ögenin } \\
\text { düşürülmesi }\end{array}$ & 218 & 0,78 & 270 & 0,96 & 488 & 1,74 \\
\hline Özne eksiltili & 183 & 0,65 & 227 & 0,81 & 410 & 1,46 \\
\hline Nesne eksiltili & 26 & 0,09 & 6 & 0,02 & 32 & 0,11 \\
\hline $\begin{array}{l}\text { Tümleç } \\
\text { eksiltili }\end{array}$ & 9 & 0,03 & 37 & 0,13 & 46 & 0,16 \\
\hline $\begin{array}{l}\text { Tamlayanın } \\
\text { düşürülmesi }\end{array}$ & 67 & 0,24 & 139 & 0,50 & 206 & 0,74 \\
\hline $\begin{array}{l}\text { Tamlananin } \\
\text { düşürülmesi }\end{array}$ & 3 & 0,01 & 14 & 0,05 & 17 & 0,06 \\
\hline $\begin{array}{l}\text { Tümcenin/ } \\
\text { Tümceciğin d. }\end{array}$ & 0 & 0 & 3 & 0,01 & 3 & 0,01 \\
\hline $\begin{array}{l}\text { Eklerin } \\
\text { düşürülmesi }\end{array}$ & 5 & 0,02 & 12 & 0,04 & 17 & 0,06 \\
\hline
\end{tabular}

Tablo 6'ya göre, öğrenci metinlerindeki eksilti kullanımının $(\chi=2,61)$ olduğu anlaşılmaktadır. Eksilti daha çok ortak ögenin düşürülmesi şeklinde yapılmıştır. Ortak ögeler içerisinde de özne eksiltili kullanımların diğerlerinden daha fazla olduğu fark 
edilmektedir. Tümcenin/tümceciğin düşürülmesi ise, en az tercih edilen eksilti şekli olarak görülmektedir.

Tablo 7: Yazma Biçimine Göre Bağlaç Kullanımı

\begin{tabular}{|c|c|c|c|c|c|c|}
\hline & \multicolumn{2}{|c|}{ Yönlendirilmiş } & \multicolumn{2}{|c|}{ Serbest } & \multicolumn{2}{|c|}{ Toplam bağdaşıklık } \\
\hline & $\mathrm{F}$ & $\chi$ & $\mathrm{F}$ & $x$ & $\mathrm{~F}$ & $\chi$ \\
\hline Bağlaçlar & 1462 & 5,22 & 2063 & 7,37 & 3525 & 12,59 \\
\hline Açıklama & 156 & 0,56 & 254 & 0,91 & 410 & 1,46 \\
\hline $\begin{array}{l}\text { Çelişki- } \\
\text { Karşıtlık }\end{array}$ & 114 & 0,41 & 279 & 0,99 & 393 & 1,40 \\
\hline $\begin{array}{l}\text { Denkleştirme- } \\
\text { Karşılaştırma- } \\
\text { Tercih }\end{array}$ & 23 & 0,08 & 74 & 0,26 & 97 & 0,35 \\
\hline Neden-Sonuç & 58 & 0,21 & 78 & 0,28 & 136 & 0,49 \\
\hline Örnekleme & 0 & 0 & 72 & 0,26 & 72 & 0,26 \\
\hline $\begin{array}{l}\text { Pekiştirme- } \\
\text { Üsteleme }\end{array}$ & 302 & 1,08 & 302 & 1,08 & 604 & 2,16 \\
\hline Siralama & 809 & 2,89 & 1004 & 3,59 & 1813 & 6,47 \\
\hline
\end{tabular}

Metinlerdeki bağlaç kullanım ortalaması $(\chi=12,59)$ olarak belirlenmiştir. Sıralama bağlaçlarının en fazla tercih edilen bağlaç türü olduğu söylenebilir. Örnekleme bağlaçları ise, en az kullanılan bağlaçlardır. Pekiştirme-üsteleme bağlaçlarında yazma biçimleri arasında sayıca kullanım farkı bulunmazken diğer tüm bağlaç türleri serbest yazılan metinlerde daha fazla kullanılmıştır.

Tablo 8: Yazma Biçimine Göre Sözcük İlişkileri Kullanımı

\begin{tabular}{lcccccc}
\hline & \multicolumn{2}{c}{ Yönlendirilmiş } & \multicolumn{2}{c}{ Serbest } & \multicolumn{2}{c}{ Toplam bağdaş1klık } \\
\hline & $\mathrm{F}$ & $\chi$ & $\mathrm{F}$ & $\chi$ & $\mathrm{F}$ & $\chi$ \\
\hline Sözcük İlişkileri & 2175 & 7,77 & 2198 & 7,85 & 4373 & 15,62 \\
\hline $\begin{array}{l}\text { Aynı sözcüğ̈n } \\
\text { yinelenmesi }\end{array}$ & 1580 & 5,64 & 1509 & 5,39 & 3089 & 11,03 \\
\hline $\begin{array}{l}\text { Aynı kökten } \\
\text { sözcüklerin } \\
\text { kullanımı }\end{array}$ & 191 & 0,68 & 115 & 0,41 & 306 & 1,09 \\
\hline $\begin{array}{l}\text { Yapı } \\
\text { yinelenmesi }\end{array}$ & 176 & 0,63 & 288 & 1,03 & 464 & 1,66 \\
\hline $\begin{array}{l}\text { Bağlama } \\
\text { uygun sözcük } \\
\text { kullanımı }\end{array}$ & 228 & 0,81 & 286 & 1,02 & 514 & 1,84 \\
\hline $\begin{array}{l}\text { Eş/Yakın } \\
\text { anlamlı }\end{array}$ & 7 & 0,02 & 16 & 0,06 & 23 & 0,08 \\
\hline Karşıt anlamlı & 15 & 0,05 & 83 & 0,30 & 98 & 0,35 \\
\hline $\begin{array}{l}\text { Üst/Alt anlamlı } \\
\text { Aynı kavram } \\
\text { alanından }\end{array}$ & 0 & 0 & 14 & 0,05 & 14 & 0,05 \\
\hline
\end{tabular}


Sözcük ilişkileri $(\chi=15,62)$ kullanım ortalaması ile biçimsel-sözlüksel bağdaşıklık içinde en fazla tercih edilendir. Öğrenciler daha çok aynı sözcüğü yineleyerek bu bağdaşıklığı oluşturmuşlardır. Metinlerde ilişkili sözcükler kullanımında; yönlendirilmiş ile serbest yazma arasında kayda değer bir farklılığın olmadığı söylenebilir.

Metinlerde bağdaşıklık ögesi kullanım düzeyinin belirlenen değişkenlere göre farklılaşan değerleri şöyle aktarılabilir:

Tablo 9: Bağdaşıklık Düzeylerinin Dil Düzeylerine Göre Dağılımı

\begin{tabular}{|c|c|c|c|c|c|c|c|c|}
\hline \multirow[b]{2}{*}{ Düzey } & \multirow[b]{2}{*}{$\mathbf{N}$} & \multirow[b]{2}{*}{$\mathbf{F}$} & \multirow[b]{2}{*}{$\chi$} & \multirow{2}{*}{$\begin{array}{l}\text { Yazma } \\
\text { biçimi }\end{array}$} & \multicolumn{4}{|c|}{ Bağdaşıklık Türleri } \\
\hline & & & & & Gönderimsel & $\begin{array}{l}\text { Biçimsel- } \\
\text { sözlüksel }\end{array}$ & F & $\chi$ \\
\hline \multirow{2}{*}{ B2 } & \multirow{2}{*}{163} & \multirow{2}{*}{357} & \multirow{2}{*}{51,27} & $\mathrm{Y}$ & 1464 & 2333 & 3797 & 23,29 \\
\hline & & & & $S$ & 1650 & 2910 & 4560 & 27,97 \\
\hline \multirow{2}{*}{$\mathrm{C} 1$} & \multirow{2}{*}{117} & \multirow{2}{*}{734} & \multirow{2}{*}{49,01} & $\mathrm{Y}$ & 1021 & 1666 & 2687 & 22,97 \\
\hline & & & & $S$ & 1142 & 1905 & 3047 & 26,04 \\
\hline
\end{tabular}

Tablo 9 incelendiğinde, B2 düzeyindeki öğrencilerin her iki türdeki metinde de C1 kurundaki öğrencilere göre daha bağdaşık yazılar yazdıkları anlaşılmaktadır.

Tablo 10: Bağdaşıklık Düzeylerinin Cinsiyete Göre Dağılımı

\begin{tabular}{|c|c|c|c|c|c|c|c|c|}
\hline \multirow[b]{2}{*}{ Cinsiyet } & \multirow[b]{2}{*}{$\mathbf{N}$} & \multirow[b]{2}{*}{$\mathbf{F}$} & \multirow[b]{2}{*}{$\chi$} & \multirow[b]{2}{*}{$\begin{array}{l}\text { Yazma } \\
\text { biçimi }\end{array}$} & \multicolumn{4}{|c|}{ Bağdaşıklık Türleri } \\
\hline & & & & & Gönderimsel & $\begin{array}{l}\text { Biçimsel- } \\
\text { sözlüksel }\end{array}$ & $\mathbf{F}$ & $\chi$ \\
\hline \multirow{2}{*}{ Kadın } & \multirow{2}{*}{105} & \multirow{2}{*}{708} & \multirow{2}{*}{54,36} & $\mathrm{Y}$ & 1019 & 1567 & 2586 & 24,63 \\
\hline & & & & $S$ & 1256 & 1866 & 3122 & 29,73 \\
\hline \multirow{2}{*}{ Erkek } & \multirow{2}{*}{175} & \multirow{2}{*}{383} & \multirow{2}{*}{47,90} & $\mathrm{Y}$ & 1466 & 2432 & 3898 & 22,27 \\
\hline & & & & S & 1536 & 2949 & 4485 & 25,63 \\
\hline
\end{tabular}

Tablo 10 değerlendirildiğinde, hem yönlendirilmiş hem de serbest yazmada kadınların metinlerdeki bağdaşıklık düzeyi kullanımının erkeklerden daha yüksek olduğu görülür.

Tablo 11: Bağdaşıklık Düzeylerinin Yaşa Göre Dağılımı

\begin{tabular}{|c|c|c|c|c|c|c|c|c|}
\hline \multirow[b]{2}{*}{ Yaş } & \multirow[b]{2}{*}{$\mathbf{N}$} & \multirow[b]{2}{*}{ F } & \multirow[b]{2}{*}{$\chi$} & \multirow[b]{2}{*}{$\begin{array}{l}\text { Yazma } \\
\text { biçimi }\end{array}$} & \multicolumn{4}{|c|}{ Bağdaşıklık Türleri } \\
\hline & & & & & Gönderimsel & $\begin{array}{l}\text { Biçimsel- } \\
\text { sözlüksel }\end{array}$ & $\mathbf{F}$ & $\chi$ \\
\hline \multirow{2}{*}{$18-25$} & \multirow{2}{*}{219} & \multirow{2}{*}{10910} & \multirow{2}{*}{49,82} & $Y$ & 1966 & 3120 & 5086 & 23,22 \\
\hline & & & & $S$ & 2179 & 3645 & 5824 & 26,59 \\
\hline \multirow{2}{*}{$26-33$} & \multirow{2}{*}{61} & \multirow{2}{*}{3181} & \multirow{2}{*}{52,15} & $Y$ & 519 & 879 & 1398 & 22,92 \\
\hline & & & & $\mathrm{S}$ & 613 & 1170 & 1783 & 29,23 \\
\hline
\end{tabular}

Tablo 11'e göre, yaşı 26 ile 33 arasında değişen öğrencilerin metinlerdeki bağdaşıklık ögesi kullanımları, kendilerinden genç öğrencilere kıyasla daha yüksektir. Yönlendirilmiş metinlerdeki bağdaşıklık ögesi kullanımında yaş farkına dayalı büyük bir değiş̧iklik görülmezken serbest yazılan metinlerde ise 26-33 yaş aralığındaki öğrencilerin daha çok bağdaşıklık ögesi kullandığı söylenebilir. 
Tablo 12: Bağdaşıklık Düzeylerinin Uyruklara Göre Dağılımı

\begin{tabular}{|c|c|c|c|c|c|c|c|c|}
\hline \multirow[b]{2}{*}{ Uyruk* } & \multirow[b]{2}{*}{$\mathbf{N}$} & \multirow[b]{2}{*}{$\mathbf{F}$} & \multirow[b]{2}{*}{$\chi$} & \multirow{2}{*}{$\begin{array}{l}\text { Yazma } \\
\text { biçimi }\end{array}$} & \multicolumn{4}{|c|}{ Bağdaşıklık Türleri } \\
\hline & & & & & Gönderimsel & $\begin{array}{l}\text { Biçimsel- } \\
\text { sözlüksel }\end{array}$ & $\mathbf{F}$ & $\chi$ \\
\hline \multirow{2}{*}{ Afrika } & \multirow{2}{*}{77} & \multirow{2}{*}{3970} & \multirow{2}{*}{51,56} & $\mathrm{Y}$ & 656 & 1157 & 1813 & 23,54 \\
\hline & & & & $S$ & 688 & 1469 & 2157 & 28,01 \\
\hline \multirow{2}{*}{ Asya } & \multirow{2}{*}{186} & \multirow{2}{*}{9222} & \multirow{2}{*}{49,58} & $\mathrm{Y}$ & 1650 & 2555 & 4205 & 22,61 \\
\hline & & & & $S$ & 1930 & 3087 & 5017 & 26,97 \\
\hline
\end{tabular}

* Amerika uyruklu 4, Avrupa uyruklu 13 öğrenci bulunmaktadır.

Tablo 12 değerlendirildiğinde, Afrika uyruklu öğrencilerin her iki yazma biçiminde de Asya uyruklulara göre bağdaşıklık düzeyi daha yüksek metinler yazdıkları söylenebilir.

Tablo 13: Bağdaşıklık Düzeylerinin Ana Dillerinin Mensup Olduğu Dil Ailesine Göre Dağılımı

\begin{tabular}{|c|c|c|c|c|c|c|c|c|}
\hline \multirow{2}{*}{$\begin{array}{l}\text { Ana dil } \\
\text { ailesi* }^{*}\end{array}$} & \multirow[b]{2}{*}{$\mathbf{N}$} & \multirow[b]{2}{*}{$\mathbf{F}$} & \multirow[b]{2}{*}{$\chi$} & \multirow{2}{*}{$\begin{array}{l}\text { Yazma } \\
\text { biçimi }\end{array}$} & \multicolumn{4}{|c|}{ Bağdaşıklık Türleri } \\
\hline & & & & & Gönderimsel & $\begin{array}{l}\text { Biçimsel- } \\
\text { sözlüksel }\end{array}$ & $\mathbf{F}$ & $\chi$ \\
\hline \multirow{2}{*}{$\begin{array}{c}\text { Hami- } \\
\text { Sami }\end{array}$} & \multirow{2}{*}{88} & \multirow{2}{*}{4032} & \multirow{2}{*}{45,82} & $\mathrm{Y}$ & 688 & 1069 & 1757 & 19,97 \\
\hline & & & & $S$ & 830 & 1445 & 2275 & 25,85 \\
\hline \multirow{2}{*}{$\begin{array}{c}\text { Hint- } \\
\text { Avrupa }\end{array}$} & \multirow{2}{*}{69} & \multirow{2}{*}{3461} & \multirow{2}{*}{50,16} & $\mathrm{Y}$ & 630 & 1037 & 1667 & 24,16 \\
\hline & & & & $S$ & 674 & 1120 & 1794 & 26 \\
\hline \multirow{2}{*}{$\begin{array}{l}\text { Nijer- } \\
\text { Kongo }\end{array}$} & \multirow{2}{*}{33} & \multirow{2}{*}{1877} & \multirow{2}{*}{56,88} & $\mathrm{Y}$ & 340 & 539 & 879 & 26,64 \\
\hline & & & & $S$ & 332 & 666 & 998 & 30,24 \\
\hline \multirow{2}{*}{$\begin{array}{l}\text { Ural- } \\
\text { Altay }\end{array}$} & \multirow{2}{*}{53} & \multirow{2}{*}{2754} & \multirow{2}{*}{51,96} & $\mathrm{Y}$ & 452 & 791 & 1243 & 23,45 \\
\hline & & & & $S$ & 620 & 891 & 1511 & 28,51 \\
\hline \multirow{2}{*}{$\begin{array}{l}\text { Diğer } \\
\text { diller }\end{array}$} & \multirow{2}{*}{37} & \multirow{2}{*}{1967} & \multirow{2}{*}{53,16} & $\mathrm{Y}$ & 375 & 563 & 938 & 25,35 \\
\hline & & & & $S$ & 336 & 693 & 1029 & 27,81 \\
\hline
\end{tabular}

* Diğer diller grubunda; Afro-Asyatik dillerinden 9, Avustronezya dillerinden 23, Çin-Tibet dillerinden 2 ve Kafkas dillerinden 3 öğrenci bulunmaktadır.

Bağdaşıklık kullanımları öğrencilerin ana dillerinin mensup olduğu dil ailelerine göre değerlendirildiğinde, ana dili Nijer-Kongo dil ailesinde yer alan öğrencilerin, her iki yazma biçiminde de, diğer öğrencilere göre daha bağdaşık metinler yazdıkları söylenebilir. Ana dili Hami-Sami dil ailesine mensup öğrencilerin ise yine her iki yazma türünde en az düzeyde bağdaşıklık ögesi kullandıkları görülmektedir.

Tablo 14: Bağdaşıklık Düzeylerinin Mezuniyete Göre Dağılımı

\begin{tabular}{|c|c|c|c|c|c|c|c|c|}
\hline \multirow[b]{2}{*}{ Mezuniyet } & \multirow[b]{2}{*}{$\mathbf{N}$} & \multirow[b]{2}{*}{$\mathbf{F}$} & \multirow[b]{2}{*}{$\chi$} & \multirow[b]{2}{*}{$\begin{array}{l}\text { Yazma } \\
\text { biçimi }\end{array}$} & \multicolumn{4}{|c|}{ Bağdaşıklık Türleri } \\
\hline & & & & & Gönderimsel & $\begin{array}{l}\text { Biçimsel- } \\
\text { sözlüksel }\end{array}$ & $\mathbf{F}$ & $\chi$ \\
\hline \multirow{2}{*}{ Lise } & \multirow{2}{*}{114} & \multirow{2}{*}{5663} & \multirow{2}{*}{49,67} & $\mathrm{Y}$ & 1055 & 1634 & 2689 & 23,59 \\
\hline & & & & $S$ & 1097 & 1877 & 2974 & 26,09 \\
\hline \multirow{2}{*}{ Lisans } & \multirow{2}{*}{100} & \multirow{2}{*}{5029} & \multirow{2}{*}{50,29} & $\mathrm{Y}$ & 896 & 1400 & 2296 & 22,96 \\
\hline & & & & $S$ & 1073 & 1660 & 2733 & 27,33 \\
\hline \multirow{2}{*}{ Lisansüstü } & \multirow{2}{*}{66} & \multirow{2}{*}{3366} & \multirow{2}{*}{51} & $\mathrm{Y}$ & 529 & 957 & 1486 & 22,51 \\
\hline & & & & $S$ & 615 & 1265 & 1880 & 28,48 \\
\hline
\end{tabular}


Tablo 14 değerlendirildiğinde, öğrencilerin eğitim seviyesi yükseldikçe metinlerindeki bağdaşıklık kullanımlarının da arttığı fark edilmektedir. Ancak yönlendirilmiş yazılarda lise mezunu öğrenciler daha fazla bağdaşıklık ögesi kullanmışken serbest yazma konusu verildiğinde lisansüstü öğrencilerin daha bağdaşık metinler yazdıkları görülmüştür.

Tablo 15: Bağdaşıklık Düzeylerinin Dil Merkezine Geliş Şekline Göre Dağılımı

\begin{tabular}{|c|c|c|c|c|c|c|c|c|}
\hline \multirow{2}{*}{$\begin{array}{l}\text { Geliş } \\
\text { şekli }\end{array}$} & \multirow[b]{2}{*}{$\mathbf{N}$} & \multirow[b]{2}{*}{$\mathbf{F}$} & \multirow[b]{2}{*}{$\chi$} & \multirow{2}{*}{$\begin{array}{l}\text { Yazma } \\
\text { biçimi }\end{array}$} & \multicolumn{4}{|c|}{ Bağdaşıklık Türleri } \\
\hline & & & & & Gönderimsel & $\begin{array}{l}\text { Biçimsel- } \\
\text { sözlüksel }\end{array}$ & $\mathbf{F}$ & $x$ \\
\hline \multirow{2}{*}{ Ücretli } & \multirow{2}{*}{55} & \multirow{2}{*}{2145} & \multirow{2}{*}{39} & $Y$ & 375 & 637 & 1012 & 18,40 \\
\hline & & & & $S$ & 437 & 696 & 1133 & 20,60 \\
\hline \multirow{2}{*}{ Burslu } & \multirow{2}{*}{225} & \multirow{2}{*}{11946} & \multirow{2}{*}{53,09} & $\mathrm{Y}$ & 2110 & 3362 & 5472 & 24,32 \\
\hline & & & & $\mathrm{S}$ & 2355 & 4119 & 6474 & 28,77 \\
\hline
\end{tabular}

Tablo 15'e göre burslu öğrenciler, iki yazma biçiminde de, ücretli öğrencilerden daha yüksek bağdaşıklık düzeyinde metinler yazmışlardır.

Tablo 16: Bağdaşıklık Düzeylerinin Türkçenin Yanı Sıra Bilinen Yabancı Dil Sayısına Göre Dağılımı

\begin{tabular}{|c|c|c|c|c|c|c|c|c|}
\hline \multirow{2}{*}{$\begin{array}{c}\text { Yabanc1 } \\
\text { dil } \\
\text { say1s1* }\end{array}$} & \multirow[b]{2}{*}{$\mathbf{N}$} & \multirow[b]{2}{*}{$\mathbf{F}$} & \multirow[b]{2}{*}{$x$} & \multirow[b]{2}{*}{$\begin{array}{l}\text { Yazma } \\
\text { biçimi }\end{array}$} & \multicolumn{4}{|c|}{ Bağdaşıklık Türleri } \\
\hline & & & & & Gönderimsel & $\begin{array}{l}\text { Biçimsel- } \\
\text { sözlüksel }\end{array}$ & $\mathbf{F}$ & $x$ \\
\hline \multirow{2}{*}{ Bir dil } & \multirow{2}{*}{98} & \multirow{2}{*}{4612} & \multirow{2}{*}{47,06} & $\mathrm{Y}$ & 852 & 1321 & 2173 & 22,17 \\
\hline & & & & $S$ & 858 & 1581 & 2439 & 24,89 \\
\hline \multirow{2}{*}{ İki dil } & \multirow{2}{*}{97} & \multirow{2}{*}{5304} & \multirow{2}{*}{54,68} & $\mathrm{Y}$ & 893 & 1440 & 2333 & 24,05 \\
\hline & & & & $S$ & 1108 & 1863 & 2971 & 30,63 \\
\hline \multirow{2}{*}{ Üç dil } & \multirow{2}{*}{53} & \multirow{2}{*}{2847} & \multirow{2}{*}{53,72} & $\mathrm{Y}$ & 497 & 861 & 1358 & 25,62 \\
\hline & & & & $S$ & 579 & 910 & 1489 & 28,09 \\
\hline
\end{tabular}

* Dört yabancı dil bilen 16 ve Türkçeden başka yabancı dil bilmeyen 16 öğrenci bulunmaktadır.

Tablo 16 incelendiğinde, Türkçenin yanı sıra bir yabancı dil daha bilen öğrencilerin metinlerindeki bağdaşıklık düzeylerinin iki ya da üç dil daha bilen öğrencilerden hayli düşük olduğu görülmektedir. Yönlendirilmiş yazılardaki bağdaşıklık ögesi kullanımının bilinen yabancı dil sayısına uygun olarak arttığı söylenebilir. Serbest yazılan metinlerde ise, bu şekilde bir artış görülmemektedir.

Tablo 17: Bağdaşıklık Düzeylerinin Türkiye'de Yaşama Süresine Göre Dağılımı

\begin{tabular}{|c|c|c|c|c|c|c|c|c|}
\hline \multirow{2}{*}{$\begin{array}{c}\text { Türkiye'de } \\
\text { yaşama } \\
\text { süresi }\end{array}$} & \multirow[b]{2}{*}{$\mathbf{N}$} & \multirow[b]{2}{*}{$\mathbf{F}$} & \multirow[b]{2}{*}{$x$} & \multirow{2}{*}{$\begin{array}{l}\text { Yazma } \\
\text { biçimi }\end{array}$} & \multicolumn{4}{|c|}{ Bağdaşıklık Türleri } \\
\hline & & & & & Gönderimsel & $\begin{array}{l}\text { Biçimsel- } \\
\text { sözlüksel }\end{array}$ & $\mathbf{F}$ & $x$ \\
\hline \multirow{2}{*}{$0-6$ ay } & \multirow{2}{*}{144} & \multirow{2}{*}{7475} & \multirow{2}{*}{51,91} & $Y$ & 1318 & 2059 & 3377 & 23,45 \\
\hline & & & & $S$ & 1475 & 2623 & 4098 & 28,46 \\
\hline \multirow{2}{*}{$7-12$ ay } & \multirow{2}{*}{95} & \multirow{2}{*}{4943} & \multirow{2}{*}{52,03} & $\mathrm{Y}$ & 884 & 1472 & 2356 & 24,80 \\
\hline & & & & $S$ & 982 & 1605 & 2587 & 27,23 \\
\hline \multirow{2}{*}{$12+$ ay } & \multirow{2}{*}{41} & \multirow{2}{*}{1673} & \multirow{2}{*}{40,80} & $\mathrm{Y}$ & 283 & 468 & 751 & 18,32 \\
\hline & & & & $S$ & 335 & 587 & 922 & 22,49 \\
\hline
\end{tabular}


Tablo 17 değerlendirildiğinde, hem yönlendirilmiş hem de serbest yazmada, Türkiye' de 0-6 ay ile 7-12 ay arasında yaşayanların 12 aydan fazla yaşayanlara göre daha bağdaşık metinler yazdıkları görülür.

Tablo 18: Bağdaşıklık Düzeylerinin Türkçe Öğrenme Süresine Göre Dağılımı

\begin{tabular}{|c|c|c|c|c|c|c|c|c|}
\hline \multirow{2}{*}{$\begin{array}{c}\text { Öğrenme } \\
\text { süresi* }^{*}\end{array}$} & \multirow[b]{2}{*}{$\mathbf{N}$} & \multirow[b]{2}{*}{$\mathbf{F}$} & \multirow[b]{2}{*}{$\chi$} & \multirow[b]{2}{*}{$\begin{array}{l}\text { Yazma } \\
\text { biçimi }\end{array}$} & \multicolumn{4}{|c|}{ Bağdaşıklık Türleri } \\
\hline & & & & & Gönderimsel & $\begin{array}{l}\text { Biçimsel- } \\
\text { sözlüksel }\end{array}$ & $\mathbf{F}$ & $\chi$ \\
\hline \multirow{2}{*}{$0-6$ ay } & \multirow{2}{*}{167} & \multirow{2}{*}{8418} & \multirow{2}{*}{50,41} & $\mathrm{Y}$ & 1446 & 2355 & 3801 & 22,76 \\
\hline & & & & $S$ & 1630 & 2987 & 4617 & 27,65 \\
\hline \multirow{2}{*}{ 7-12 ay } & \multirow{2}{*}{92} & \multirow{2}{*}{4769} & \multirow{2}{*}{51,84} & $\mathrm{Y}$ & 861 & 1387 & 2248 & 24,43 \\
\hline & & & & $S$ & 983 & 1538 & 2521 & 27,40 \\
\hline
\end{tabular}

*Türkçe öğrenme süresi 12 aydan fazla olan 21 öğrenci bulunmaktadır.

Tablo 18'e göre, serbest konuda yazılan metinlerdeki bağdaşıklık oranında, Türkçe öğrenme sürelerinin bariz bir etkisi tespit edilmemiş olup yönlendirilmiş metinlerde Türkçe öğrenme süresi uzadıkça az bir farkla da olsa metinlerdeki bağdaşıklık düzeyinin arttı̆̆ söylenebilir.

Tablo 19: Bağdaşıklık Düzeylerinin Türk Arkadaş Sayısına Göre Dağılımı

\begin{tabular}{|c|c|c|c|c|c|c|c|c|}
\hline \multirow[b]{2}{*}{$\begin{array}{l}\text { Arkadaş } \\
\text { sayıs1* }\end{array}$} & \multirow[b]{2}{*}{$\mathbf{N}$} & \multirow[b]{2}{*}{$\mathbf{F}$} & \multirow[b]{2}{*}{$x$} & \multirow[b]{2}{*}{$\begin{array}{l}\text { Yazma } \\
\text { biçimi }\end{array}$} & \multicolumn{4}{|c|}{ Bağdaşıklık Türleri } \\
\hline & & & & & Gönderimsel & $\begin{array}{l}\text { Biçimsel- } \\
\text { sözlüksel }\end{array}$ & $\mathbf{F}$ & $\chi$ \\
\hline \multirow{2}{*}{ 1-15 kişi } & \multirow{2}{*}{189} & \multirow{2}{*}{9304} & \multirow{2}{*}{49,23} & $\mathrm{Y}$ & 1610 & 2696 & 4306 & 22,78 \\
\hline & & & & $S$ & 1814 & 3184 & 4998 & 26,44 \\
\hline \multirow{2}{*}{$\begin{array}{c}16-30 \\
\text { kişi }\end{array}$} & \multirow{2}{*}{44} & \multirow{2}{*}{2364} & \multirow{2}{*}{53,73} & $\mathrm{Y}$ & 428 & 668 & 1096 & 24,91 \\
\hline & & & & $S$ & 429 & 839 & 1268 & 28,82 \\
\hline \multirow{2}{*}{ 30+ kişi } & \multirow{2}{*}{33} & \multirow{2}{*}{1793} & \multirow{2}{*}{54,33} & $\mathrm{Y}$ & 351 & 476 & 827 & 25,06 \\
\hline & & & & $S$ & 374 & 592 & 966 & 29,27 \\
\hline
\end{tabular}

* Hiç Türk arkadaşı olmayan 14 öğrenci bulunmaktadır.

Tablo 19 değerlendirildiğinde, öğrencilerin Türk arkadaş sayısı arttıkça her iki yazma biçiminde de kullandıkları bağdaşıklık ögesi sayısının arttı̆̆ı söylenebilir.

Tablo 20: Bağdaşıklık Düzeylerinin Türk Televizyon Kanalları İzleme Durumuna Göre Dağılımı

\begin{tabular}{|c|c|c|c|c|c|c|c|c|}
\hline \multirow{2}{*}{$\begin{array}{c}\text { Tv } \\
\text { izleme }\end{array}$} & \multirow[b]{2}{*}{$\mathbf{N}$} & \multirow[b]{2}{*}{$\mathbf{F}$} & \multirow[b]{2}{*}{$\chi$} & \multirow{2}{*}{$\begin{array}{l}\text { Yazma } \\
\text { biçimi }\end{array}$} & \multicolumn{4}{|c|}{ Bağdaşıklık Türleri } \\
\hline & & & & & Gönderimsel & $\begin{array}{l}\text { Biçimsel- } \\
\text { sözlüksel }\end{array}$ & $\mathbf{F}$ & $\chi$ \\
\hline \multirow{2}{*}{ Hayır } & \multirow{2}{*}{80} & \multirow{2}{*}{3807} & \multirow{2}{*}{47,59} & $\mathrm{Y}$ & 715 & 1163 & 1878 & 23,47 \\
\hline & & & & $S$ & 749 & 1180 & 1929 & 24,11 \\
\hline \multirow{2}{*}{ Evet } & \multirow{2}{*}{200} & \multirow{2}{*}{10284} & \multirow{2}{*}{51,42} & $\mathrm{Y}$ & 1770 & 2836 & 4606 & 23,03 \\
\hline & & & & $S$ & 2043 & 3635 & 5678 & 28,39 \\
\hline
\end{tabular}

Tablo 20 incelendiğinde, yönlendirilmiş yazıların bağdaşıklık düzeylerinde Türk televizyon kanallarını izleme durumuna göre ortalama kullanım açısından bariz bir farklılık görülmemektedir. Ancak serbest metinlerde bahsi geçen kanalları izleyen öğrenciler, diğerlerinden daha bağdaşık yazılar yazmışlardır. 
Tablo 21: Bağdaşıklık Düzeylerinin Türk Televizyon Kanallarını İzleme Sıklığına Göre Dağılımı

\begin{tabular}{|c|c|c|c|c|c|c|c|c|}
\hline \multirow{2}{*}{$\begin{array}{c}\text { Tv } \\
\text { izleme } \\
\text { sıklığı }\end{array}$} & \multirow[b]{2}{*}{$\mathbf{N}$} & \multirow[b]{2}{*}{$\mathbf{F}$} & \multirow[b]{2}{*}{$x$} & \multirow[b]{2}{*}{$\begin{array}{l}\text { Yazma } \\
\text { biçimi }\end{array}$} & \multicolumn{4}{|c|}{ Bağdaşıklık Türleri } \\
\hline & & & & & Gönderimsel & $\begin{array}{l}\text { Biçimsel- } \\
\text { sözlüksel }\end{array}$ & $\mathbf{F}$ & $\chi$ \\
\hline \multirow{2}{*}{ Her gün } & \multirow{2}{*}{52} & \multirow{2}{*}{2564} & \multirow{2}{*}{49,31} & $\mathrm{Y}$ & 400 & 697 & 1097 & 21,10 \\
\hline & & & & $\mathrm{S}$ & 509 & 958 & 1467 & 28,21 \\
\hline \multirow{2}{*}{$\begin{array}{l}\text { Haftada } \\
\text { birkaç } \\
\text { gün }\end{array}$} & \multirow[b]{2}{*}{110} & \multirow[b]{2}{*}{5492} & \multirow[b]{2}{*}{49,93} & $\mathrm{Y}$ & 929 & 1543 & 2472 & 22,47 \\
\hline & & & & S & 1039 & 1981 & 3020 & 27,45 \\
\hline \multirow{2}{*}{$\begin{array}{l}\text { Ayda } \\
\text { birkaç } \\
\text { gün }\end{array}$} & \multirow[b]{2}{*}{38} & \multirow[b]{2}{*}{2244} & \multirow[b]{2}{*}{59,05} & $\mathrm{Y}$ & 452 & 592 & 1044 & 27,47 \\
\hline & & & & $S$ & 494 & 706 & 1200 & 31,58 \\
\hline
\end{tabular}

Tablo 21'e göre, hem yönlendirilmiş hem de serbest yazma metinlerinde, ayda birkaç gün Türk televizyon kanallarını izleyen öğrencilerin her gün ya da haftada birkaç gün izleyen öğrencilerden daha bağdaşık yazılar yazdıkları anlaşılmaktadır.

Tablo 22: Bağdaşıklık Düzeylerinin Cep Telefonu Kullanma Diline Göre Dağılımı

\begin{tabular}{|c|c|c|c|c|c|c|c|c|}
\hline \multirow{2}{*}{$\begin{array}{l}\text { Telefonu } \\
\text { kullanma } \\
\text { dili* }^{*}\end{array}$} & \multirow[b]{2}{*}{$\mathbf{N}$} & \multirow[b]{2}{*}{$\mathbf{F}$} & \multirow[b]{2}{*}{$x$} & \multirow{2}{*}{$\begin{array}{l}\text { Yazma } \\
\text { biçimi }\end{array}$} & \multicolumn{4}{|c|}{ Bağdaşıklık Türleri } \\
\hline & & & & & Gönderimsel & $\begin{array}{l}\text { Biçimsel- } \\
\text { sözlüksel }\end{array}$ & $\mathbf{F}$ & $\chi$ \\
\hline \multirow{2}{*}{ Türkçe } & \multirow{2}{*}{92} & \multirow{2}{*}{4462} & \multirow{2}{*}{48,50} & $\mathrm{Y}$ & 815 & 1340 & 2155 & 23,42 \\
\hline & & & & $S$ & 837 & 1470 & 2307 & 25,08 \\
\hline \multirow{2}{*}{ Ana dil } & \multirow{2}{*}{40} & \multirow{2}{*}{1750} & \multirow{2}{*}{43,75} & $\mathrm{Y}$ & 265 & 467 & 732 & 18,30 \\
\hline & & & & $S$ & 351 & 667 & 1018 & 25,45 \\
\hline \multirow{2}{*}{$\begin{array}{l}\text { Üçüncü } \\
\text { bir dil }\end{array}$} & \multirow{2}{*}{134} & \multirow{2}{*}{7023} & \multirow{2}{*}{52,41} & $\mathrm{Y}$ & 1261 & 1968 & 3229 & 24,10 \\
\hline & & & & $S$ & 1462 & 2332 & 3794 & 28,31 \\
\hline
\end{tabular}

* Telefonunu birden fazla dil ile kullanan 14 öğrenci bulunmaktadır.

Tablo 22'ye göre, cep telefonunu ana dili ile kullanan öğrencilerin yönlendirilmiş metinlerde diğer öğrencilere göre daha az bağdaşıklık ögesi kullandıkları görülürken serbest yazma için böyle bir durum söz konusu değildir. Her iki yazma biçiminde de cep telefonunu üçüncü bir dilde kullananların daha bağdaşık metinler yazdıkları anlaşılmıştır.

Tablo 23: Bağdaşıklık Düzeylerinin İnterneti Kullanma Diline Göre Dağılımı

\begin{tabular}{|c|c|c|c|c|c|c|c|c|}
\hline \multirow{2}{*}{$\begin{array}{l}\text { Interneti } \\
\text { kullanma } \\
\text { dili }\end{array}$} & \multirow[b]{2}{*}{$\mathbf{N}$} & \multirow[b]{2}{*}{$\mathbf{F}$} & \multirow[b]{2}{*}{$x$} & \multirow{2}{*}{$\begin{array}{l}\text { Yazma } \\
\text { biçimi }\end{array}$} & \multicolumn{4}{|c|}{ Bağdaşıklık Türleri } \\
\hline & & & & & Gönderimsel & $\begin{array}{l}\text { Biçimsel- } \\
\text { sözlüksel }\end{array}$ & $\mathbf{F}$ & $\chi$ \\
\hline \multirow{2}{*}{ Türkçe } & \multirow{2}{*}{54} & \multirow{2}{*}{2637} & \multirow{2}{*}{48,83} & $\mathrm{Y}$ & 492 & 768 & 1260 & 23,33 \\
\hline & & & & $S$ & 497 & 880 & 1377 & 25,50 \\
\hline \multirow{2}{*}{ Ana dil } & \multirow{2}{*}{93} & \multirow{2}{*}{4269} & \multirow{2}{*}{45,90} & $\mathrm{Y}$ & 751 & 1168 & 1919 & 20,63 \\
\hline & & & & $S$ & 881 & 1469 & 2350 & 25,27 \\
\hline \multirow{2}{*}{$\begin{array}{l}\text { Üçüncü } \\
\text { bir dil }\end{array}$} & \multirow{2}{*}{103} & \multirow{2}{*}{5600} & \multirow{2}{*}{54,37} & $\mathrm{Y}$ & 991 & 1561 & 2552 & 24,78 \\
\hline & & & & $\mathrm{S}$ & 1117 & 1931 & 3048 & 29,59 \\
\hline \multirow{2}{*}{$\begin{array}{l}\text { Birden } \\
\text { çok dil }\end{array}$} & \multirow{2}{*}{30} & \multirow{2}{*}{1585} & \multirow{2}{*}{52,83} & $\mathrm{Y}$ & 251 & 502 & 753 & 25,10 \\
\hline & & & & $\mathrm{S}$ & 297 & 535 & 832 & 27,73 \\
\hline
\end{tabular}


Tablo 23 değerlendirildiğinde, interneti üçüncü bir dilde kullanan öğrencilerin diğer öğrencilere göre daha bağdaşık yazılar yazdıkları anlaşılmaktadır. Yönlendirilmiş yazmada interneti birden çok dil ile kullananların, serbest yazmada ise üçüncü bir dille kullananların daha bağdaşık metinler yazdıkları görülmektedir. En düşük bağdaşık ögesi kullanımı ise, interneti ana dillerinde kullanan öğrencilerdedir.

Tablo 24: Bağdaşıklık Düzeylerinin Türkçe Öğrenmenin Zor Olduğunu Düşünme Durumuna Göre Dağılımı

\begin{tabular}{|c|c|c|c|c|c|c|c|c|}
\hline \multirow[b]{2}{*}{ Zorluk } & \multirow[b]{2}{*}{$\mathbf{N}$} & \multirow[b]{2}{*}{$\mathbf{F}$} & \multirow[b]{2}{*}{$x$} & \multirow{2}{*}{$\begin{array}{l}\text { Yazma } \\
\text { biçimi }\end{array}$} & \multicolumn{4}{|c|}{ Bağdaşıklık Türleri } \\
\hline & & & & & Gönderimsel & $\begin{array}{l}\text { Biçimsel- } \\
\text { sözlüksel }\end{array}$ & $\mathbf{F}$ & $\chi$ \\
\hline \multirow{2}{*}{ Kolay } & \multirow{2}{*}{145} & \multirow{2}{*}{7439} & \multirow{2}{*}{51,30} & $\mathrm{Y}$ & 1279 & 2130 & 3409 & 23,51 \\
\hline & & & & $\mathrm{S}$ & 1498 & 2532 & 4030 & 27,79 \\
\hline \multirow{2}{*}{ Zor } & \multirow{2}{*}{135} & \multirow{2}{*}{6652} & \multirow{2}{*}{49,27} & $\mathrm{Y}$ & 1206 & 1869 & 3075 & 22,78 \\
\hline & & & & $S$ & 1294 & 2283 & 3577 & 26,50 \\
\hline
\end{tabular}

Türkçe öğrenmenin zor olduğunu düşünen öğrenciler her iki yazma biçiminde de metinlerinde daha az sayıda bağdaşıklık ögesi kullanmışlardır.

Tablo 25: Bağdaşıklık Düzeylerinin Türkçe Öğrenme Amacına Göre En Çok İhtiyaç Duyacaklarını Düşündükleri Öğrenme Alanına Göre Dağılımı

\begin{tabular}{|c|c|c|c|c|c|c|c|c|}
\hline \multirow[b]{2}{*}{ İhtiyaç* } & \multirow[b]{2}{*}{$\mathbf{N}$} & \multirow[b]{2}{*}{$\mathbf{F}$} & \multirow[b]{2}{*}{$x$} & \multirow[b]{2}{*}{$\begin{array}{l}\text { Yazma } \\
\text { biçimi }\end{array}$} & \multicolumn{4}{|c|}{ Bağdaşıklık Türleri } \\
\hline & & & & & Gönderimsel & $\begin{array}{l}\text { Biçimsel- } \\
\text { sözlükssel }\end{array}$ & $\mathbf{F}$ & $\chi$ \\
\hline \multirow{2}{*}{ Konuşma } & \multirow{2}{*}{101} & \multirow{2}{*}{4915} & \multirow{2}{*}{48,66} & $\mathrm{Y}$ & 848 & 1371 & 2219 & 21,97 \\
\hline & & & & $S$ & 964 & 1732 & 2696 & 26,69 \\
\hline \multirow{2}{*}{ Okuma } & \multirow{2}{*}{44} & \multirow{2}{*}{2251} & \multirow{2}{*}{51,16} & $\mathrm{Y}$ & 433 & 668 & 1101 & 25,02 \\
\hline & & & & $S$ & 418 & 732 & 1150 & 26,14 \\
\hline \multirow{2}{*}{ Yazma } & \multirow{2}{*}{50} & \multirow{2}{*}{2450} & \multirow{2}{*}{49} & $\mathrm{Y}$ & 357 & 664 & 1021 & 20,42 \\
\hline & & & & $S$ & 488 & 941 & 1429 & 28,58 \\
\hline
\end{tabular}

* Dinleme becerisini 13 öğrenci, dil bilgisini 26 öğrenci ihtiyaç olarak görmektedir. Ayrıca 46 öğrenci, birden fazla beceri alanı belirttiğinden analiz dışı tutulmuştur.

Türkçe öğrenme amaçlarına göre en çok okuma becerisine ihtiyacı olacağını düşünen öğrenciler, metinleri daha bağdaşık yazmışlardır. Metinlerdeki bağdaşıklık düzeyleri yazma türüne göre ayrıldığında ise, yönlendirilmiş yazmada okuma becerisine ihtiyaç duyacağını düşünen öğrencilerin, serbest yazmada ise daha çok yazma becerisine ihtiyaçları olacağını düşünen öğrencilerin yazılarında daha bağdaşık ifadeler kullandıkları anlaşılmaktadır. 
Tablo 26: Bağdaşıklık Düzeylerinin Türkçe Öğrenirken En Çok Zorlandıkları Öğrenme Alanına Göre Dağılımı

\begin{tabular}{|c|c|c|c|c|c|c|c|c|}
\hline \multirow[b]{2}{*}{ Zorlanma* } & \multirow[b]{2}{*}{$\mathbf{N}$} & \multirow[b]{2}{*}{$\mathbf{F}$} & \multirow[b]{2}{*}{$\chi$} & \multirow[b]{2}{*}{$\begin{array}{l}\text { Yazma } \\
\text { biçimi }\end{array}$} & \multicolumn{4}{|c|}{ Bağdaşıklık Türleri } \\
\hline & & & & & Gönderimsel & $\begin{array}{l}\text { Biçimsel- } \\
\text { sözlüksel }\end{array}$ & $\mathbf{F}$ & $\chi$ \\
\hline \multirow{2}{*}{ Dinleme } & \multirow{2}{*}{47} & \multirow{2}{*}{2144} & \multirow{2}{*}{45,62} & $\mathrm{Y}$ & 423 & 628 & 1051 & 22,36 \\
\hline & & & & $S$ & 362 & 731 & 1093 & 23,25 \\
\hline \multirow{2}{*}{ Konuşma } & \multirow{2}{*}{55} & \multirow{2}{*}{2941} & \multirow{2}{*}{53,47} & $\mathrm{Y}$ & 577 & 810 & 1387 & 25,22 \\
\hline & & & & $S$ & 582 & 972 & 1554 & 28,25 \\
\hline \multirow{2}{*}{ Okuma } & \multirow{2}{*}{44} & \multirow{2}{*}{2314} & \multirow{2}{*}{52,59} & $\mathrm{Y}$ & 404 & 677 & 1081 & 24,57 \\
\hline & & & & $S$ & 474 & 759 & 1233 & 28,02 \\
\hline \multirow{2}{*}{ Yazma } & \multirow{2}{*}{77} & \multirow{2}{*}{3865} & \multirow{2}{*}{50,19} & $\mathrm{Y}$ & 619 & 1101 & 1720 & 22,34 \\
\hline & & & & $S$ & 799 & 1346 & 2145 & 27,86 \\
\hline \multirow{2}{*}{ Dil bilgisi } & \multirow{2}{*}{34} & \multirow{2}{*}{1595} & \multirow{2}{*}{46,91} & $\mathrm{Y}$ & 256 & 456 & 712 & 20,94 \\
\hline & & & & $S$ & 285 & 598 & 883 & 25,97 \\
\hline
\end{tabular}

* 23 öğrenci birden fazla beceri alanı belirttiğinden analiz dışı tutulmuştur.

Tablo 26 incelendiğinde, Türkçe öğrenirken en çok konuşmada zorlandığını düşünen öğrencilerin metinlerde daha fazla bağdaşıklık unsuru kullandığı görülürken en fazla dinlemede zorlandığını belirten öğrenciler ise en az düzeyde bağdaşıklık ögesi kullandığı fark edilmektedir.

Yönlendirilmiş yazmada en çok dil bilgisi alanında zorlandığını belirten öğrencilerin, serbest yazmada ise daha çok dinlemede zorlandığını söyleyen öğrencilerin metinlerinin diğer öğrencilerden daha az bağdaşık olduğu söylenebilir.

Tablo 27: Bağdaşıklık Düzeylerinin Türkçe Öğrenirken En Başarılı Olduklarını Düşündükleri Öğrenme Alanına Göre Dağılımı

\begin{tabular}{|c|c|c|c|c|c|c|c|c|}
\hline \multirow[b]{2}{*}{ Başarılı* } & \multirow[b]{2}{*}{$\mathbf{N}$} & \multirow[b]{2}{*}{$\mathbf{F}$} & \multirow[b]{2}{*}{$\chi$} & \multirow{2}{*}{$\begin{array}{l}\text { Yazma } \\
\text { biçimi }\end{array}$} & \multicolumn{4}{|c|}{ Bağdaşıklık Türleri } \\
\hline & & & & & Gönderimsel & $\begin{array}{l}\text { Biçimsel- } \\
\text { sözlüksel }\end{array}$ & $\mathbf{F}$ & $\chi$ \\
\hline \multirow{2}{*}{ Dinleme } & \multirow{2}{*}{31} & \multirow{2}{*}{1578} & \multirow{2}{*}{50,90} & $\mathrm{Y}$ & 260 & 428 & 688 & 22,19 \\
\hline & & & & $S$ & 354 & 536 & 890 & 28,71 \\
\hline \multirow{2}{*}{ Konuşma } & \multirow{2}{*}{72} & \multirow{2}{*}{3241} & \multirow{2}{*}{45,01} & $\mathrm{Y}$ & 566 & 979 & 1545 & 21,46 \\
\hline & & & & $S$ & 640 & 1056 & 1696 & 23,56 \\
\hline \multirow{2}{*}{ Okuma } & \multirow{2}{*}{44} & \multirow{2}{*}{2377} & \multirow{2}{*}{54,02} & $\mathrm{Y}$ & 440 & 669 & 1109 & 25,20 \\
\hline & & & & $S$ & 421 & 847 & 1268 & 28,82 \\
\hline \multirow{2}{*}{ Yazma } & \multirow{2}{*}{45} & \multirow{2}{*}{2265} & \multirow{2}{*}{50,33} & $\mathrm{Y}$ & 373 & 635 & 1008 & 22,40 \\
\hline & & & & $S$ & 464 & 793 & 1257 & 27,93 \\
\hline \multirow{2}{*}{$\begin{array}{c}\text { Dil } \\
\text { bilgisi }\end{array}$} & \multirow{2}{*}{65} & \multirow{2}{*}{3256} & \multirow{2}{*}{50,09} & $\mathrm{Y}$ & 560 & 940 & 1500 & 23,08 \\
\hline & & & & $S$ & 609 & 1147 & 1756 & 27,01 \\
\hline
\end{tabular}

* 23 öğrenci birden fazla beceri alanı belirttiğinden analiz dışı tutulmuştur.

Tablo 27'ye göre, en başarılı oldukları öğrenme alanının okuma olduğunu belirten öğrencilerin diğer öğrencilerden daha bağdaşık metinler yazdıkları anlaşılmaktadır. Yönlendirilmiş yazmada da sonuç bu şekildedir. 
Kendilerini en çok konuşma becerisinde başarılı bulan öğrencilerin ise yazılarında en az düzeyde bağdaşık unsuru kullandığı tespit edilmiştir. Serbest yazılan metinlerde, bağdaşıklık ögesi kullanımı birbirine çok yakın olduğu görülmekte ve en az bağdaşıklık ögesi kullanan grubun yine kendilerini konuşma becerisinde başarılı bulan öğrenciler olduğu anlaşılmaktadır.

Tablo 28: Bağdaşıklık Düzeylerinin Türkçe Yazarken Hata Yapmaktan Korkma Durumuna Göre Dağılımı

\begin{tabular}{|c|c|c|c|c|c|c|c|c|}
\hline \multirow{2}{*}{$\begin{array}{l}\text { Hatadan } \\
\text { korkmak }\end{array}$} & \multirow[b]{2}{*}{$\mathbf{N}$} & \multirow[b]{2}{*}{$\mathbf{F}$} & \multirow[b]{2}{*}{$\chi$} & \multirow{2}{*}{$\begin{array}{l}\text { Yazma } \\
\text { biçimi }\end{array}$} & \multicolumn{4}{|c|}{ Bağdaşıklık Türleri } \\
\hline & & & & & Gönderimsel & $\begin{array}{l}\text { Biçimsel- } \\
\text { sözlüksel }\end{array}$ & $\mathbf{F}$ & $\chi$ \\
\hline \multirow{2}{*}{ Hayır } & \multirow{2}{*}{66} & \multirow{2}{*}{3080} & \multirow{2}{*}{46,67} & $\mathrm{Y}$ & 505 & 955 & 1460 & 22,12 \\
\hline & & & & $S$ & 609 & 1011 & 1620 & 24,54 \\
\hline \multirow{2}{*}{ Biraz } & \multirow{2}{*}{137} & \multirow{2}{*}{6966} & \multirow{2}{*}{50,85} & $\mathrm{Y}$ & 1281 & 1894 & 3175 & 23,17 \\
\hline & & & & $S$ & 1396 & 2395 & 3791 & 27,67 \\
\hline \multirow{2}{*}{ Evet } & \multirow{2}{*}{77} & \multirow{2}{*}{4045} & \multirow{2}{*}{52,53} & $\mathrm{Y}$ & 699 & 1150 & 1849 & 24,01 \\
\hline & & & & $S$ & 787 & 1409 & 2196 & 28,52 \\
\hline
\end{tabular}

Tablo 28 incelendiğinde, Türkçe yazı yazarken hata yapmaktan korkan öğrencilerin her iki yazma türünde de daha bağdaşık yazılar yazarken hatadan korkmayan öğrencilerin ise daha az bağdaşıklık ögesi kullandığı anlaşılmaktadır.

Tablo 29: Bağdaşıklık Düzeylerinin Ders Dışı Zamanlarda Türkçe Yazılar Yazma Durumuna Göre Dağılımı

\begin{tabular}{|c|c|c|c|c|c|c|c|c|}
\hline \multirow{2}{*}{$\begin{array}{l}\text { Türkçe } \\
\text { yazma }\end{array}$} & \multirow[b]{2}{*}{$\mathbf{N}$} & \multirow[b]{2}{*}{$\mathbf{F}$} & \multirow[b]{2}{*}{$x$} & \multirow{2}{*}{$\begin{array}{l}\text { Yazma } \\
\text { biçimi }\end{array}$} & \multicolumn{4}{|c|}{ Bağdaşıklık Türleri } \\
\hline & & & & & Gönderimsel & $\begin{array}{l}\text { Biçimsel- } \\
\text { sözlüksel }\end{array}$ & $\mathbf{F}$ & $x$ \\
\hline \multirow{2}{*}{ Hayır } & \multirow{2}{*}{155} & \multirow{2}{*}{7350} & \multirow{2}{*}{47,42} & $\mathrm{Y}$ & 1342 & 2112 & 3454 & 22,28 \\
\hline & & & & $S$ & 1408 & 2488 & 3896 & 25,13 \\
\hline \multirow{2}{*}{ Evet } & \multirow{2}{*}{125} & \multirow{2}{*}{6741} & \multirow{2}{*}{53,93} & $\mathrm{Y}$ & 1143 & 1887 & 3030 & 24,24 \\
\hline & & & & $S$ & 1384 & 2327 & 3711 & 29,69 \\
\hline
\end{tabular}

Tablo 29'a göre, ders dişı zamanlarda da Türkçe metinler yazan öğrencilerin, her iki türde de, yazmayanlara göre daha bağdaşık yazılar yazdıkları anlaşılmaktadır.

Tablo 30: Bağdaşıklık Düzeylerinin Ders Dışı Zamanlarda Ana Dilde Yazılar Yazma Durumuna Göre Dağılımı

\begin{tabular}{|c|c|c|c|c|c|c|c|c|}
\hline \multirow{2}{*}{$\begin{array}{c}\text { Ana } \\
\text { dilde } \\
\text { yazma }\end{array}$} & \multirow[b]{2}{*}{$\mathbf{N}$} & \multirow[b]{2}{*}{$\mathbf{F}$} & \multirow[b]{2}{*}{$\chi$} & \multirow[b]{2}{*}{$\begin{array}{l}\text { Yazma } \\
\text { biçimi }\end{array}$} & \multicolumn{4}{|c|}{ Bağdaşıklık Türleri } \\
\hline & & & & & Gönderimsel & $\begin{array}{l}\text { Biçimsel- } \\
\text { sözlüksel }\end{array}$ & $\mathbf{F}$ & $\chi$ \\
\hline \multirow{2}{*}{ Hayır } & \multirow{2}{*}{149} & \multirow{2}{*}{7700} & \multirow{2}{*}{51,68} & $\mathrm{Y}$ & 1389 & 2183 & 3572 & 23,97 \\
\hline & & & & $S$ & 1460 & 2668 & 4128 & 27,70 \\
\hline \multirow{2}{*}{ Evet } & \multirow{2}{*}{131} & \multirow{2}{*}{6391} & \multirow{2}{*}{48,79} & $\mathrm{Y}$ & 1096 & 1816 & 2912 & 22,23 \\
\hline & & & & $S$ & 1332 & 2147 & 3479 & 26,56 \\
\hline
\end{tabular}

Tablo 30 incelendiğinde, ders dişı zamanlarda ana dilinde metinler yazan öğrenciler hem yönlendirilmiş hem de serbest yazılarında diğer öğrencilere göre daha düşük oranda bağdaşıklık ögesi kullanmışlardır. 


\section{TARTIŞMA}

Araştırma sonuçlarına göre; iki metnin toplamında öğrenci başına düşen bağdaşıklık ögesi kullanımı 50,32'dir. Serbest konuda yazılan metinlerin bağdaşıklık düzeylerinin yönlendirilmiş yazılara göre daha yüksek olduğu sonucuna ulaşılmıştır. Oysaki beklenen sonuç, birbirinin devamı niteliğinde verilen resimler hakkında daha bağdaşık metinler yazılmasıdır. Malgwi'nin (2015) İngilizce öğrenen Nijeryalı öğrencilerle gerçekleştirdiği çalışmasının sonucu da bir dizi resim kullanılarak yazılan metinlerde yapılan gönderimlerin standart İngilizce ile daha uyumlu olduğu yönündedir. Araştırmacı da bu durumun, metin oluşturma için resimlerin kullanılmış olmasından kaynaklandığını düşünmektedir. Ancak belirtildiği gibi, yabancı öğrenciler serbest metinleri daha bağdaşık yazmışlardır. Bu sonuç, verilen resimlerin öğrencileri yönlendirirken aynı zamanda kendilerine sunulan çerçeveden dışarı çıkamadıkları için kısıtlanmış olmalarından kaynaklandığını düşündürmektedir.

Metinlerde gönderimsel bağdaşıklık türlerinden öncül/bağımsız gönderimin daha fazla kullanıldığı anlaşılmaktadır. Öğrencilerin bağımsız gönderim ögelerinden kişi adıllarını en fazla, aitlik adılını ise en az sayıda tercih ettikleri görülür. Karakoç-Öztürk ve Dağıstanlığlu (2018) ile Yıldırım'ın (2016) çalışmalarında da kişi adıllarının diğer gönderim ögelerinden daha çok kullandıkları sonucuna ulaşılmıştır. Bağımlı gönderim unsurlarından en çok kişi ekleri kullanılırken belirtme durumu eki ise, en düşük oranda kullanılmıştır.

Her iki metinde de daha çok biçimsel-sözlüksel bağdaşıklığa dayalı unsurların kullanıldığı tespit edilmiştir. Öğrencilerin metinlerindeki biçimsel-sözlüksel bağdaşıklığı, diğer alt başlıklara kıyasla, genellikle sözcük ilişkileri kurarak sağladıkları fark edilir. Mantı (2017) da araştırmasında aynı sonuca ulaşmıştır. Yabancı öğrencilerle çalışan diğer araştırmacılar (Aramak, 2016; Karakoç-Öztürk \& Dağıstanlıŏlu, 2018; Yıldırım, 2016) ise, bağlama ögelerinin öğrencilerin en çok kullandıkları bağdaşıklık aracı olduğunu saptamışlardır. Bu farklılık, metinlerde aynı sözcüğün yinelenmesine dayalı kullanımların çalışmalardaki sayım farkına dayalı olabilir. Çünkü her bir kullanım için sözcügün tekrar sayılıp sayılmadığı, Mantı' nın (2017) çalışması dışında, kıyaslama yapılan araştırmalarda yeterince açık ifade edilmemiştir.

Çalışma sonucunda değiştirimin, biçimsel-sözlüksel bağdaşıklık türlerinden en az tercih edileni olduğu anlaşılmıştır. Bu bulgu, yabancı dil olarak Türkçe öğrenenler ile yapılan farklı çalışmalarla (Karakoç-Öztürk \& Dağıstanlıŏlu, 2018; Mant1, 2017; Yıldırım, 2016) da desteklenebilir. Öğrencilerin yazılarında yer verdikleri değiştirim kullanımları ele alındığında, daha çok tümceye/tümceciğe dayalı değiştirim yaptıkları fark edilir. Literatürdeki çalışmalarda (Karakoç-Öztürk \& Dağıstanlıŏlu, 2018; Yıldırım, 2016) da bu sonuca benzer şekilde, tümceye dayalı değiştirimin en sık kullanılan değiştirim kategorisi olduğu belirtilmiştir. Eyleme dayalı değiştirim ise, çalışmaya katılan yabancı öğrenciler tarafından en az kullanılan değiştirim türü olmuştur.

Metinlerdeki eksilti kullanımı değerlendirildiğinde; eksiltinin daha çok ortak ögenin düşürülmesi biçiminde yapıldığı, onun da alt birimleri ele alındığında metinlerde en çok öznenin eksiltildiği görülür. Tümcenin/tümceciğin düşürülmesi ise oldukça düşük bir oranda kullanılmıştır. Bu hususlarda, Yıldırım (2016) da benzer sonuçlara ulaşmıştır.

Bağlaç kullanımında; sıralama bağlaçlarının en fazla tercih edilen bağlaç türü olduğu belirlenmiştir. Bu sonuç Aramak (2016) ve Yıldırım'ın (2016) çalışmalarında alınan sonuçlarla benzerlik göstermektedir. Sıralama görevinde kullanılan bağlaçların; tümceleri ve 
paragrafları bağlamanın yanı sıra sözcükleri de birbirine bağlamada sıkça kullanılması, bu durumun olası bir nedeni olabilir. Örnekleme bağlaçlarının ise, öğrenci yazılarında en az kullanılan bağlaçlar olduğu anlaşılmıştır.

Sözcük ilişkileri kurulması, biçimsel-sözlüksel bağdaşıklık birimleri arasında en fazla tercih edilendir ve öğrenciler, daha çok aynı sözcüğü yineleyerek bu ilişkileri sağlamışlardır. Kafes (2012) de İngilizce öğretmeni adaylarıyla gerçekleştirdiği çalışmasında, katılımcıların hem ana dillerinde hem de yabancı dilde yazdıkları metinlerindeki sözcük uyumunu sağlarken en çok aynı sözcüksel ögenin yinelenmesine başvurduklarını tespit etmiştir. Ana dil ile yabancı dilde yazılan metinlerdeki bağdaşıklığı karşılaştıran bir başka çalışmada Connor (1984), ana dili İngilizce olanların sözcüksel bağdaşıklık ögesi kullanımlarının ikinci dil olarak İngilizce öğrenenlerin metinlerine oranla daha fazla çeşitlilik gösterdiği sonucuna ulaşmıştır. Çalışma sonucunda, aynı kökten sözcük kullanımının diğer maddelere oranla daha az tercih edildiği görülür. Bu sonuç, öğrencilerin bir sözcüğün farklı türlerinin kullanımına yönelik bir tercihlerinin olmadığını göstermektedir.

Bulundukları dil seviyeleri dikkate alındığında; B2 düzeyindeki öğrencilerin C1 kurundaki öğrencilere göre hem yönlendirilmiş hem de serbest olarak daha bağdaşık metinler yazdıkları sonucuna ulaşılmıştır. Aramak'ın (2016) araştırmasında da C1 düzeyindeki öğrencilerin metinlerdeki bağdaşıklık aracı kullanma düzeyinin çoğunlukla zayıf olduğu sonucuna ulaşılmıştır. Mantı'nın (2017) çalışmasında ise; bağdaşıklık araçları kullanımında, bağlama ögelerinin kullanımı dışında, dil düzeyinin yükselmesine dayalı periyodik olarak bir artış gözlenmemiştir. Bu sonuca benzer şekilde, Jin (2001) de İngilizce öğrenen Çinlilerle yürüttüğü çalışmasında, ileri yeterlikteki öğrencilerin sadece bazı kategorilerde orta düzeydekilere göre anlamlı oranda daha fazla bağlayıcı öge kullandıklarını söyler.

Hem yönlendirilmiş hem de serbest yazmada kadınların erkeklere oranla daha bağdaşık metinler yazdıkları görülmüştür. Aramak'ın (2016) çalışmasında ise, yabancı öğrencilerin öğretim etkinlikleri uygulanmadan önce yazdıkları metinlerde, bağdaşıklık araçlarını kullanma düzeylerinin yine kadınlar lehine anlamlı bir farklılık gösterdiği ancak uygulamadan sonraki yazılarında cinsiyetin anlamlı bir farklılık oluşturmadığı saptanmıştır.

Yabancı öğrencilerden ileri yaşlarda olanların özellikle serbest konulu metinlerde kendilerinden genç olanlara kıyasla daha fazla bağdaşıklık ögesi kullandıkları görülür. Altunkaya ve Ateş (2017) ise, yabancı öğrencilerin yazma becerisi puanlarının yaşa göre anlamlı derecede farklılaştığını ve daha genç öğrencilerin daha yüksek puanlar aldıklarını tespit etmişlerdir. Fakat bahsi geçen çalışmada, yazma becerisi genel olarak puanlandığından birebir karşılaştırma yapmak olası değildir.

Öğrencilerin uyrukları göz önüne alındığında, Afrika uyruklu öğrencilerin, her iki yazma biçiminde de, Asya uyruklu öğrencilere nazaran daha bağdaşık metinler yazdıkları söylenebilir.

Her iki yazma biçiminde de ana dili Nijer-Kongo dil ailesinde yer alan öğrencilerin daha fazla bağdaşıklık ögesi kullandıkları görülmüştür. Ana dili Hami-Sami dil ailesine mensup öğrencilerin ise, yazdıkları metinler en az düzeyde bağdaşıklıktır. Bu sonuçlar, öğrencilerinin sahip olduğu ana dillerinin yazdıkları metinlerdeki bağdaşıklık ögesi kullanımları üzerinde etkili olduğunu gösterir. Şimşek (2017) de çalışmasında; yabancı öğrencilerin ana dilleri ve bu dillerin köken ve yapı bakımından dil ailelerinin, öğrencilerin 
yazma becerisindeki başarılarını anlamlı derecede etkilediği sonucuna ulaşmıştır. Bahsi geçen çalışmada; yazma derslerinin sınav evrakları değerlendirilmiş ve en düşük puanları, ana dili Hami-Sami dil ailesinden olan öğrencilerin aldıkları tespit edilmiştir.

Serbest yazılan metinlerde öğrencilerin mezun oldukları eğitim seviyesi yükseldikçe metinlerindeki bağdaşıklık kullanımlarının da arttığı fark edilmiştir.

Burslu öğrenciler her iki yazma biçiminde de ücretli öğrencilerden daha bağdaşık yazılar yazmışlardır. Bu sonuç, çeşitli sınavlara girerek Türkiye'de eğitim almaya hak kazanan öğrencilerin, çalışmaya devam ederek başarılarını sürdürdükleri şeklinde yorumlanabilir. Bu durum ayrıca, ücretli öğrencilerin bir kısmının Türkçeyi yükseköğrenim görme amacıyla öğrenmemeleri ve yazma becerisine yeterince önem vermeyip daha iyi yazmak için çaba göstermemiş olabilmelerinden de kaynaklanabilir.

Yönlendirilmiş yazılardaki bağdaşıklık ögesi kullanımının bilinen yabancı dil sayısına uygun olarak arttı̆̆1 söylenebilir. Serbest yazılan metinlerde ise, bu şekilde bir artış bulunmamaktadır.

Türkiye'de yaşama süresi 12 aydan fazla olan öğrencilerin, daha az yaşamış öğrencilere göre hayli düşük oranda bağdaşıklık ögesi kullandıkları fark edilmiştir. Bu sonucun beklenenin aksine bir bulgu olduğu söylenebilir. Çünkü hedef dilin konuşulduğu ülkede yaşamanın o dili daha iyi öğrenmeye katkı sağlayacağı düşünülmektedir.

Yabancı öğrencilerin Türkçe öğrenme sürelerinin arttıkça az bir farkla da olsa yazdıkları metinlerdeki bağdaşıklık düzeyinin arttı̆̆ı söylenebilir. Öğrencilere verilen öğretim süresi fazlalaştıkça dil becerilerine yönelik gelişimlerinin artması beklenen bir sonuçtur.

Öğrencilerin Türk arkadaş sayısı arttıkça yazdıkları metinlerdeki bağdaşıklık ögesi kullanım oranının da arttığı görülmüştür. Türk arkadaş sayısı $30^{\prime}$ dan daha fazla olan öğrenciler her iki yazma biçiminde de diğer öğrencilere kıyasla daha bağdaşık metinler yazmışlardır. Bu sonuç, öğrencilerin günlük hayatlarında Türk arkadaşlarıyla yaptıkları sohbetlerde Türkçeyi daha çok kullanmış olma durumlarının bir getirisi olarak yorumlanabilir.

Türk televizyon kanallarını izleyen öğrencilerin serbest metinlerde daha bağdaşık yazılar yazdıkları anlaşılmıştır. Kanalları izleme sıklıkları kıyaslandığında, ayda birkaç gün televizyon izleyen öğrencilerin hem yönlendirilmiş hem de serbest metinlerinde, her gün veya haftada birkaç gün izleyen öğrencilerden daha bağdaşık yazılar yazdıkları görülür.

Cep telefonunu ana dili ile kullanan öğrencilerin yönlendirilmiş metinlerde daha az bağdaşıklık ögesi kullanırken üçüncü bir dilde kullananların her iki yazma biçiminde de daha bağdaşık metinler yazdıkları anlaşılmıştır. Bu sonuçlar günlük hayatta ana dili kullanımının artmasının öğrencilerin Türkçe yazma becerilerini olumsuz etkilediği şeklinde yorumlanabilir.

İnterneti üçüncü bir dilde kullananlar ile birden çok dilde kullanan öğrenciler, diğer öğrencilere göre daha bağdaşık yazılar yazmışlardır. En düşük bağdaşık ögesi kullanımı ise, interneti ana dillerinde kullanan öğrencilerdedir. Burada da ana dili kullanımının Türkçe metinlerdeki bağdaşıklı̆̆a olumsuz bir etkisi söz konusudur. 
Türkçe öğrenmenin zor olduğunu düşünen öğrenciler her iki metinde de daha az sayıda bağdaşıklık ögesi kullanmışlar. Bu hususta, duyuşsal süreçlerin bilişsel öğrenmeleri etkilediği düşünülebilir.

Yabancı öğrencilerden Türkçe öğrenme amaçlarına göre ihtiyaç duyacaklarını düşündükleri öğrenme alanı göz önüne alındığında, yönlendirilmiş metinlerde en çok okuma becerisine ihtiyacı olacağını düşünenlerin daha bağdaşık yazılar yazdıkları söylenebilir. Serbest metinlerde ise daha çok yazma becerisine ihtiyaçları olacağını düşünenler, daha fazla bağdaşıklık ögesi kullanmışlardır.

Yönlendirilmiş yazmada en çok dil bilgisi alanında zorlandığını belirten öğrencilerin, serbest yazmada ise daha çok dinlemede zorlandığını söyleyen öğrencilerin metinlerinin diğer öğrencilerden daha az bağdaşık olduğu söylenebilir.

En başarılı oldukları öğrenme alanının okuma olduğunu belirten öğrencilerin diğer öğrencilerden daha bağdaşık metinler yazdıkları anlaşılmıştır. Bu durum, muhtemelen çok okuyan öğrencilerin sözcük dağarcıklarının daha geniş ve kendilerini ifade etme becerilerinin daha yüksek olmasının bir getirisidir. Araştırmalarında Türkçe kitap, gazete ve dergi okumanın Türkçe metinler yazma becerileri üzerindeki etkisini inceleyen Altunkaya ve Ateş (2017) ise, bu materyalleri okuma durumu ve sıklığının yabancı öğrencilerin yazma becerisi puanlarına anlamlı derecede etki etmediği sonucuna ulaşmışlardır. Kendilerini en çok konuşma becerisinde başarılı bulan öğrencilerin ise yazılarında en az düzeyde bağdaşıklık ögesi kullandığı tespit edilmiştir. Bu sonuç, öğrencilerin yazılı anlatımı sözlü anlatımla bir tutarak düşünmeden, gelişigüzel ve tümceleri birbirine bağlama gereği duymadan yazmış olabilmeleri ihtimallerinden kaynaklanabilir.

Türkçe yazılar yazarken hata yapmaktan korkan öğrenciler, her iki yazma biçiminde de, diğerlerine göre daha bağdaşık yazılar yazmışlardır. Bu sonucun, öğrencilerin metinlerini hata yapma korkusu ile daha titiz ve düşünerek yazmış olabilmelerinden ortaya çıktığı düşünülmektedir.

Ders dışı zamanlarda da Türkçe metinler yazan yabancı öğrencilerin yazmayanlara oranla, her iki yazma biçiminde de, daha bağdaşık yazılar yazdıkları saptanmıştır. Yazma becerisinin daha çok yazdıkça gelişeceği göz önüne alındığında, bu sonuç beklenen bir durumdur.

Ders dışı zamanlarda ana dillerinde metinler yazan öğrencilerin ise hem yönlendirilmiş hem de serbest yazmada daha az bağdaşıklık ögesi kullandıkları fark edilmiştir. Yeni bir dil öğrenirken ana dili kullanımını en aza indirmek gerekliliği bu sonuçla da desteklenebilir.

\section{SONUÇ}

Sonuç olarak, serbest konuda yazılan metinlerin yönlendirilmiş yazılara göre daha bağdaşık olduğu söylenebilir. Her iki metinde de biçimsel-sözlüksel bağdaşıklığa daha fazla yer verilmiştir.

Metinlerin bağdaşıklık düzeyi hem yönlendirilmiş hem de serbest yazmada bazı değiş̧kenler açısından paralel sonuçlar vermektedir. Bahsi geçen değişkenler şöyle sıralanabilir: dil düzeyi, cinsiyet, uyruk, ana dillerinin mensup olduğu dil ailesi, dil merkezine gelişs şekli, Türkiye'de yaşama süresi, Türk arkadaş sayısı, Türk televizyon 
kanallarını izleme sıklı̆̆ı, Türkçe öğrenmenin zor olduğunu düşünme durumu, Türkçe öğrenirken en başarılı olduklarını düşündükleri öğrenme alanı, Türkçe yazarken hata yapmaktan korkma durumu, ders dışı zamanlarda Türkçe yazılar yazma durumu ve ders dışı zamanlarda ana dilde yazılar yazma durumu.

Metinlerin bağdaşıklık düzeyleri bazı değişkenler açısından ise yönlendirilmiş ve serbest yazmada farklı sonuçlar vermiştir. Bu değişkenler şu şekildedir: yaş, mezuniyet, Türkçenin yanı sıra bilinen yabancı dil sayısı, Türkçe öğrenme süresi, Türk televizyon kanallarını izleme durumu, cep telefonu kullanma dili, interneti kullanma dili, Türkçe öğrenme amaçlarına göre en çok ihtiyaç duyacakları öğrenme alanı, Türkçe öğrenirken en çok zorlandıkları öğrenme alanı.

\section{SUMMARY}

Cohesion is related with the surface level of text and can be inferred through grammatical features. Cohesion is basically divided into two groups: referential and formallexical. Referential cohesion is the recall of an element specified or to be specified in the text by using a different grammar element rather than repeating it in the same way. The new phrase can be used to refer to the previous word or even to the paragraph. Anaphora/independent reference items are personal pronouns, reflexive pronoun, demonstrative pronouns, possessive pronoun, indefinite pronoun, demonstrative adjectives, and adverbs. Cataphora/dependent reference items are possessive suffixes, accusative suffix, genitive suffix and personal ending. Formal-lexical cohesion is generally a type of cohesion provided by words. Substitution, ellipsis, conjunctions, and word relationships are under this framework.

The main aim of this study is to determine the level of cohesion of texts written by international students learning Turkish as a foreign language. Furthermore, this study aims to compare and contrast the two different texts written by the learners based on level of cohesion, and investigate the differences with determined variables. Coherent texts; allows the author to convey the subject he/she wants to convey in a more accurate and understandable way. Thus, a healthier communication is provided. In addition to individuals whose native language is Turkish, those who learn Turkish as a second or foreign language must have this feature in order to ensure the effectiveness of written communication.

This study can be identified as a descriptive research that follows survey method. Document analysis was carried out on the learner texts. The participants of the study are 280 international students from six different universities. There were 163 students with B2 and 117 students with $\mathrm{C} 1$ language proficiency levels. The data were gathered through three different forms given to the participants: general background information form, guidedwriting form, and free-writing form. In order to carry out the data analysis procedure, qualitative data were digitalized.

The results of the study including both of the texts show that the use of cohesion element per student was determined as 50,32. The results show that the level of cohesion in free-writing was higher than the level of cohesion in guided-writing. In the texts, it is understood that the anaphora/independent reference is used more than the types of referential cohesion. It is seen that, among the independent reference items, the students prefer personal pronouns the most and possessive pronoun the least. In both texts, it was 
determined that the students use the items based on formal-lexical coherence. As a result of the study, it is understood that change is the least preferred form of formal-lexical correlation. Considering the use of ellipsis in the texts; it is seen that the ellipsis is done in the form of lowering common items, and when its subunits are considered, it is seen that the subjects are mostly subtracted. The reduction of the sentence was used at a very low rate. In the use of conjunctions; coordinate connectors are the most preferred types of connectors. The establishment of word relations is the most preferred among formal-lexical cohesion units and students have achieved these relations by repeating the same word. The results show that the level of using cohesive devices varies in terms of some variables. 


\section{KAYNAKÇA}

Altunkaya, F. (1987). Cohesion in Turkish a survey of cohesive devices in prose literature (Doktora tezi). Erişim adresi: https://tez.yok.gov.tr/UlusalTezMerkezi/giris.jsp.

Altunkaya, H. \& Ateş, A. (2017). Yabancı dil olarak Türkçe öğrenenlerin yazma özyeterlikleri ile yazılı anlatım becerileri arasındaki ilişki. Erzincan Üniversitesi Ĕ̆itim Fakültesi Dergisi, 19(3), 86-103. doi: 10.17556/erziefd.338356.

Aramak, K. (2016). Türkçenin yabancı dil olarak öğretiminde bağdaşıklık araçlarının kullanım düzeyi üzerine bir araştırma (Yüksek lisans tezi). Erişim adresi: https://tez.yok.gov.tr/UlusalTezMerkezi/giris.jsp.

Aşkın-Balc1, H. (2018). Metindilbilimin ABC'si. İstanbul: Say Yay.

Ayata-Şenöz, C. (2005). Metindilbilim ve Türkçe. İstanbul: Multilingual.

Aydın, İ. (2012). İlköğretim 8. sınıf Türkçe ders kitabı'nın 'duygular' temasında yer alan okuma metinlerine metindilbilimsel bir yaklaşım. Turkish Studies, 7(3), 381-407. doi: 10.7827/TurkishStudies.3377.

Bae, J. (2001). Cohesion and coherence in children's written English: Immersion and Englishonly classes. Issues in Applied Linguistics, 12(1), 51-88. Erişim adresi: https://escholarship.org/uc/item/3hb2z0s4.

Bamberg, B. (1983). What makes a text coherent? College Composition and Communication, 34(4), 417-429. doi: 10.2307/357898.

Baykul, Y. (2010). Eğitimde ve psikolojide ölçme: klâsik test teorisi ve uygulaması (2. bs). Ankara: Pegem.

Beaugrande, R. A. \& Dressler, W. U. (1986). Introduction to text linguistics (3. bs). New York: Longman.

Büyüköztürk, Ş., Kılıç-Çakmak, E., Akgün, Ö. E., Karadeniz, Ş. \& Demirel, F. (2015). Bilimsel araştırma yöntemleri (19. bs). Ankara: Pegem.

Cohen, L. \& Manion, L. (1998). Research methods in education (4. bs). Routledge: London.

Connor, U. (1984). A study of cohesion and coherence in English as a second language students' writing. Paper in Linguistics, 17(3), 301-316. doi: 10.1080/08351818409389208.

Coşkun, E. (2005). İlköğretim öğrencilerinin öyküleyici anlatımlarında bağdaşıklı, tutarlılık ve metin elementleri (Doktora tezi). Erişim adresi: https://tez.yok.gov.tr/UlusalTezMerkezi/giris.jsp.

Coşkun-Ögeyik, M. (2008). Metinlerarasılık ve yazın eğitimi. Ankara: Anı Yay.

Çelik, A. \& Demirbilek, S. (2006). Metin bilgisi. Cümle ve metin bilgisi içinde (s. 79-205). İstanbul: Lisans Yay.

Demir, T. (2004). Türkçe dilbilgisi. Ankara: Kurmay Yay.

Dilidüzgün, Ş. (2017). Metindilbilim ve Türkçe öğretimi uygulamalı bir yaklaşım. Ankara: Anı.

Dillon, T. (1992). Nuclear sentences: Teaching cohesion to L2 business writers. The Bulletin, 55, 9-15. doi: 10.1177/108056999205500103.

Elyıldırım, S. (2008). Ömer Seyfettin öykülerinde artgönderim kullanımı. A.Ü. Türkiyat Araştırmalar Enstitüsü Dergisi, 36, 121-146. Erişim adresi: http://www.turkiyatjournal.com/Makaleler/536182238_Selma\%20ELYILDIRIM.pdf. 
Ergin, M. (2009). Edebiyat ve eğitim fakültelerinin Türk dili ve edebiyatı bölümleri için Türk dil bilgisi. İstanbul: Bayrak.

Erkul, R. (2007). Cümle ve metin bilgisi (2. bs). Ankara: Anı.

Günay, V. D. (2013). Metin bilgisi (4. bs). İstanbul: Papatya.

Gürbüz, S. \& Şahin, F. (2018). Sosyal bilimlerde araştırma yöntemleri (5. bs). Ankara: Seçkin.

Güven, A. Z. (2014). Mustafa Kutlu'nun hikâyelerinde bağdaşıklık ve tutarlılık. International Journal of Language Academy, 2(4), 599-609. doi: 10.18033/ijla.153.

Halliday, M. A. K. \& Hassan, R. (1987). Cohesion in English (8. bs). Singapore: Longman Singapore Publishers.

İmer, K., Kocaman, A. \& Özsoy, A. S. (2011). Dilbilim sözlüğ̈̈. İstanbul: Boğaziçi Üniversitesi Yayınevi.

İşeri, K. (2017). Sözden yazıya dile gelen metin (2. bs). Ankara: Pegem.

Jin, W. (2001). A quantitative study of cohesion in Chinese graduate students' writing: Variations across genres and proficiency levels. The Symposium on Second Language Writing at Purdue University. September 15-16, 2000. Indiana: EDRS, 3-34.

Kafes, H. (2012). Lexical cohesion: An issue only in the foreign language?. English Language Teaching, 5(3), 83-94. doi: 10.5539/elt.v5n3p83.

Karabağ, S. \& İşsever, S. (1996). Edinim sürecinde bağdaşıklık. IX. Dilbilim Kurultayı Bildirileri Kitapçı̆̆ı içinde (s. 221-235). Bolu: Abant İzzet Baysal Üniversitesi Yay.

Karakoç-Öztürk, B. \& Dağıstanlığlu, B. E. (2018). Yabancı dil olarak Türkçe öğrenen öğrencilerin yazdıkları öyküleyici metinlerin bağdaşıklık görünümlerinin incelenmesi. Mersin Üniversitesi Eğitim Fakültesi Dergisi, 14(1), 332-354. doi: 10.17860/mersinefd.356640.

Karasar, N. (2011). Bilimsel araştırma yöntemi (22. bs). Ankara: Nobel.

Karatay, H. (2010). Bağdaşıklık araçlarını kullanma düzeyi ile tutarlı metin yazma arasındaki ilişki. Mustafa Kemal Üniversitesi Sosyal Bilimler Enstitüsü Dergisi, 7(13), 373-385. Erişim adresi: http://docplayer.biz.tr/18597219-Bagdasiklik-araclarini-kullanma-duzeyi-iletutarli-metin-yazma-arasindaki-iliski-1.html.

Korkmaz, Z. (2007). Türkiye Türkçesi grameri şekil bilgisi (2. bs). Ankara: Türk Dil Kurumu Yay.

Malgwi, G. J. (2015). Report on a study of reference cohesion in texts of Nigerian Esl students: Implications for the classroom. International Journal of English Language Teaching, 3(5), 20-24. Erişim adresi: http://www.eajournals.org/wpcontent/uploads/Report-On-a-Study-of-Reference-Cohesion-in-Texts-of-Nigerian-ESLStudents-Implications-for-the-Classroom1.pdf.

Mant1, M. İ. (2017). Türkçe öğrenen Mısırlı öğrencilerin yazılı anlatım çalışmalarında bağdaşıklık (Kahire örneği) (Yüksek lisans tezi). Erişim adresi: https://tez.yok.gov.tr/UlusalTezMerkezi/giris.jsp.

Melanlığlu, D. (2017). Dil öğretiminde metin ve metin seçimi. H. Develi vd. (Ed.), Uygulamalı Türkçenin yabancı dil olarak öğretimi el kitabı (C. 2 ) içinde (s. 111-186). İstanbul: Kesit Yay.

Neuman, W. L. (2016). Toplumsal araştırma yöntemleri / nitel ve nicel yaklaşımlar (C. 2). Ankara: Yayınodasi.

SEFAD, 2020; (43): 273-300 
Özbek, Ö. Y. (2011). Ölçme araçlarında bulunması istenen nitelikler. S. Tekindal (Ed.), Eğitimde ölçme ve değerlendirme içinde (s. 44-88). Ankara: Pegem.

Özkan, B. (2004). Metindilbilimi, metindilbilimsel bağdaşıklık ve Haldun Taner'in "Onikiye Bir Var" adlı öyküsünde metindilbilimsel bağdaşıklık görünümleri. Çukurova Üniversitesi Sosyal Bilimler Enstitüsü Dergisi, 13(1), 167-184. Erişim adresi: https://dergipark.org.tr/tr/download/article-file/50160.

Palmer, J. C. (1999). Coherence and cohesion in the English language classroom: The use of lexical reiteration and pronominalisation. Relc Journal, 30(2), 61-85. doi: 10.1177/003368829903000204.

Seçkin, P., Arslan, N. \& Ergenç, S. (2014). Bağdaşıklık ve tutarlılık bakımından lise ve üniversite öğrencilerinin yazılı anlatım becerileri. Uluslararası Türkçe Edebiyat Kültür Eğitim Dergisi, 3(1), 340-353. doi: 10.7884/teke.269.

Struthers, L., Lapadat, J. C. \& MacMillan, P. D. (2013). Assessing cohesion in children's writing: Development of a checklist. Assessing Writing, 18, 187-201. doi: 10.1016/j.asw.2013.05.001

Subaşı-Uzun, L. (1995). Orhon yazıtlarının metindilbilimsel yapısı. Ankara: Simurg Yay.

Şimşek, P. (2017). Türkçenin yabancı dil olarak öğretiminde, öğrencilerin ana dilleri ve mensup olduklar dil ailelerinin Türkçe yazma becerisine etkisi (Doktora tezi). Erişim adresi: https://tez.yok.gov.tr/UlusalTezMerkezi/giris.jsp.

Tekşan, K. (2013). Yazma eğitimi. İstanbul: Kriter Yay.

Tierney, R. J. \& Mosenthal, J. H. (1981). The cohesion concept's relationship to the coherence of text (Technical Report No: 221). Urbana: Center for the Study of Reading.

Toptaş, H. (2016). Türkçe dersleri 2: sesbilgisi, tümce, anlatım, metin dilbilimi. İstanbul: Papatya.

Torusdağ, G. \& Aydın, İ. (2017). Metindilbilim ve örnek metin çözümlemeleri. Ankara: Pegem.

Uzun, L. (2013). Metindilbilim: temel ilke ve kavramlar. A. S. Özsoy \& Z. Erk Emeksiz (Ed.), Genel dilbilim-II içinde (s.152-180). Eskişehir: Anadolu Üniversitesi Yay.

Uzun-Subaşı, L. (2004). Metin üretimi. C. İleri (Ed.), Türkçe sözlü ve yazllı anlatım içinde (s. 2138). Eskişehir: Anadolu Üniversitesi Açıöğretim Fakültesi Yay.

Üstünova, K. (2002). Dil yazıları. Ankara: Akçağ Yay.

Yaylagül, Ö. (2015). Göstergebilim ve dilbilim. Ankara: Hece.

Yıldırım, A. \& Şimşek, H. (2011). Sosyal bilimlerde nitel araştırma yöntemleri (8. bs). Ankara: Seçkin.

Yıldırım, S. (2016). B1 düzeyinde Türkçe öğrenen yabancıların yazılı anlatımlarının bağdaşıklık düzeyleri (Gazi Tömer örneği) (Yüksek lisans tezi). Erişim adresi: https://tez.yok.gov.tr/UlusalTezMerkezi/giris.jsp. 